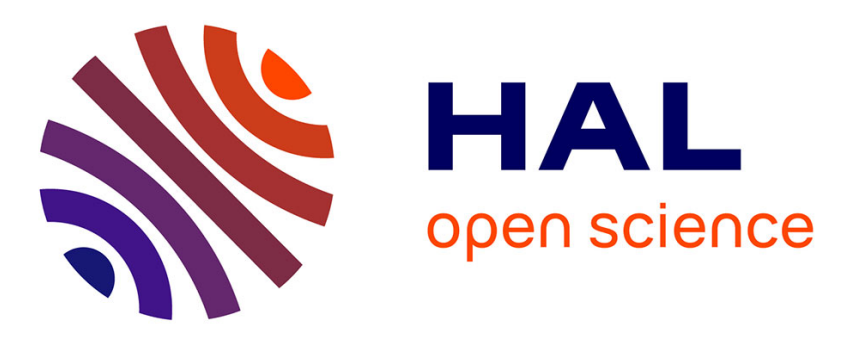

\title{
Times are changing: A new chronology for Holocene volcanic events and hydro-sedimentary history recorded in the Sarliève marsh (central France)
}

\author{
Alfredo Mayoral Pascual, Gérard Vernet, Olivier Voldoire, Jean-François \\ Berger, Yannick Miras, Emmanuelle Defive
}

\section{To cite this version:}

Alfredo Mayoral Pascual, Gérard Vernet, Olivier Voldoire, Jean-François Berger, Yannick Miras, et al.. Times are changing: A new chronology for Holocene volcanic events and hydro-sedimentary history recorded in the Sarliève marsh (central France). Quaternary Science Reviews, 2021, 272, pp.107237. 10.1016/j.quascirev.2021.107237 . hal-03385683

\section{HAL Id: hal-03385683 https://hal.science/hal-03385683}

Submitted on 19 Oct 2021

HAL is a multi-disciplinary open access archive for the deposit and dissemination of scientific research documents, whether they are published or not. The documents may come from teaching and research institutions in France or abroad, or from public or private research centers.
L'archive ouverte pluridisciplinaire HAL, est destinée au dépôt et à la diffusion de documents scientifiques de niveau recherche, publiés ou non, émanant des établissements d'enseignement et de recherche français ou étrangers, des laboratoires publics ou privés. 
MAYORAL, Alfredo ${ }^{a, b *}$; VERNET, Gérard ${ }^{c}$; VOLDOIRE, Olivier ${ }^{a}$; BERGER, Jean-François ${ }^{d}$; MIRAS,

(a) CNRS, GEOLAB, Université Clermont Auvergne, Clermont-Ferrand, France.

(b) Catalan Institute of Classical Archaeology, Tarragona, Spain

(c) Université Clermont Auvergne, CNRS, INRAP, LMV, Clermont-Ferrand, France

(d) CNRS, UMR 5600, EVS-IRG \& Université Lyon 2, Lyon, France

(e) CNRS, UMR7194, Histoire Naturelle de I'Homme Préhistorique, Muséum National d'Histoire

Naturelle, Institut de Paléontologie Humaine, Paris, France

*Corresponding author. amayoral@icac.cat; alfredo.mayoral@uca.fr

Abstract: This paper presents the first well-dated palaeoenvironmental study from the Sarliève marsh, a unique sedimentary record in the Limagne plain of central France, where all previous studies suffered from unreliable chronologies. We developed an accurate radiocarbon-based agedepth model and performed high-resolution multi-proxy sedimentological and geochemical analysis on a new sediment core from the heart of the sedimentary basin, improving the chronology and Holocene palaeoenvironmental interpretations. We found six potential (crypto)tephra fallouts (c. $9750,8500,7500,7400,6300$, and $5800 \mathrm{cal}$ yr BP) that enrich the Holocene tephrostratigraphy in Limagne, five of which were not previously documented in the sediments of the marsh. We also detected, for the first time, an array of volcanic phenomena such as degassing episodes (c. 6950 and 6050 cal yr BP), ash leaching phases (10250-9750, 8500-7400, and 5800-5100 cal yr BP), and 
earthquakes (c. 6800, 6600, 6050, 6100, and $1600 \mathrm{cal} \mathrm{yr} \mathrm{BP),} \mathrm{suggesting} \mathrm{a} \mathrm{hitherto} \mathrm{unsuspected}$ period of high volcanic activity in the area between 7500 and 5800 cal yr BP. This increased activity appears to have caused a massive forcing of hydrosedimentary dynamics in the catchment in the Middle Holocene, by supplying significant volumes of fine volcanic ash to the palustrine basin, and thereby questioning the current Holocene morpho-sedimentary narrative for Limagne. The basin became a permanent freshwater lake after the Mid-Holocene climatic shift, and detrital influxes likely due to anthropogenic soil erosion appeared c. 5500 cal yr BP and grew steadily after 5000 cal yr BP, with a marked lull between 3600 and 3000 cal yr BP, perhaps because of a phase of settlement abandonments during the middle and early-late Bronze age. A series of lacustrine low-stands (c. $4750-4600,3750-3600,3350-3200$ and $2950-2800$ cal yr BP) that correlate strongly with western alpine lake records do not seem to have caused significant changes in the anthropogenic impact on soils modifying the sedimentary supply. Our results suggest that this lake could have been artificially drained c. 2550 cal yr BP, several centuries earlier than previously estimated, allowing us to hypothesize that Early Iron age societies already had substantial capacity to modify the hydraulic environment. Hydromorphic conditions developed thereafter, including complex short-lived marshy phases in late Roman times.

Keywords: Palaeoenvironment, Age-depth modelling, Cryptotephra, Volcanic activity, Hydrosedimentary processes, Sedimentology, Geochemistry, Socio-environmental interaction, Holocene, Massif Central 51 


\section{INTRODUCTION}

Over recent decades, studies concerning Holocene palaeoenvironments and socio-environmental interactions have progressed substantially (e.g. Wang et al., 2013; Kaufman et al., 2020). Increasingly robust approaches are often based on nuanced interpretations of case-by-case studies to correctly discuss causality in socio-environmental trajectories (e.g. Lespez et al., 2016). The common spine of these approaches is accurate dating, because precise, reliable, and comparable chronologies are crucial for any interpretation (Blaauw, 2012; Armit et al., 2014). Unfortunately, precise chronological data are still lacking for large areas of Europe, preventing a fine integration between palaeoenvironmental and archaeological datasets.

This is typically the case in the intra-mountainous carbonated plain of Limagne in central France, where sedimentary archives adequate for palaeoenvironmental studies are very rare. One of the few exceptions is the Sarliève marsh, where the first studies started in the 1960's (Gachon, 1963). This wetland is a depression located $5 \mathrm{~km}$ south of Clermont-Ferrand at the feet of the Chaîne des Puys, a volcanic range that produced several well-known eruptions, tephra fallouts, and lava flows during the Lateglacial and Mid-Holocene (Boivin et al., 2017) (Fig. 1A-B). The basin is nowadays a drained plain with a NW-SE elongated shape and an outlet at its northern border (Fig. 1C). The lithology of the catchment is relatively diverse (Fig. 1D): Miocene basalts, breccias, and tuffs overly the Oligocene carbonated sedimentary rocks of the Limagne formation (BRGM, 1973; Bouiller, 1979). Differential erosion has carved prominent buttes and plateaus topped by volcanic rocks, which dominate the lowlands. The surficial formations include colluvium of variable thickness, nature, and lithology (see Fig. 1D). The lowlands include Pleistocene alluvium from the river Allier (Fig. 1B) and alluvio-colluvial infillings affected by hydromorphy, the so-called "Limagne complex", in the drained Sarliève depression. The climate is oceanic to semi-continental (Köppen $\mathrm{Cfb}$ ), with cold and relatively dry winters and hot and stormy summers (Joly et al., 2010). From an archaeological perspective, the 
sector is relatively well known, and multi-period remains and settlements (Neolithic to late Roman) have been documented around the Sarliève basin, especially at the summit of the Gergovie plateau (Trément et al., 2007).

The Sarliève marsh was the object of several geological and palaeoenvironmental studies in the 2000s. The morphology of the basin and the geometry of its sedimentary infilling are well-known: it is divided into northern and southern sub-basins, which were separated by a threshold during the first half of the Holocene and then connected later, and contain 5 to $6 \mathrm{~m}$ of Lateglacial to Holocene fine sedimentary infilling, including several lacustrine phases (Fourmont, 2006; Hinschberger et al., 2006). The palaeohydrological, geomorphological, and sedimentological evolution from the Lateglacial have also been largely documented: four major phases controlled by a combination of climatic (earlier phases) and anthropogenic (later phases) factors have been detected, before the modern drainage of the depression in recent centuries. An endorheic saline lake during the Early Holocene was followed by detrital and laminated facies during the Middle Holocene, indicating highly variable hydrosedimentary conditions that evolved to a permanent carbonated lake during the Middle to Late Holocene. Finally, the lake was drained in the late Protohistory, although later marshy phases are known (Bréhéret et al., 2003; Vernet, 2005; Fourmont, 2006; Bréhéret et al., 2008; Fourmont et al. 2009). The sedimentary budget of the catchment since the Lateglacial has also been addressed, with an acceleration from approximately $5300 \mathrm{cal}$ yr BP being interpreted as anthropogenic (Macaire et al., 2010). Finally, in its peripheral areas, the basin also includes at least two volcanic fallouts, identified as the tephra CF1 (c. 13,000 cal yr BP; Vernet et al., 2011; Vernet, 2013, 2019) and the "Tephra de Sarliève" (uncertain age, around 5000 cal yr BP). Both fallouts were likely to have dissolved in central areas of the basin under aquatic conditions (Miallier et al., 2004; Vernet, 2005; Fourmont et al., 2006). Palaeoenvironmental studies have also been performed on several cores from deeper areas of the marsh or deep test pits (Fourmont, 2006; Prat, 2006; Trément et al., 2007; Macaire et al., 2010), allowing a reconstruction of the vegetation and landscape, hydrological conditions, and human activities since the beginning of the Neolithic. All of the abovementioned 
studies were integrated into a socio-environmental model for the sector (Trément et al., 2007; Trément, 2011) that was used to discuss the roles of Holocene hydro-climatic variability and human activities on landscape evolution during the Holocene, identifying thresholds in the IInd century BC and Roman periods.

Unfortunately, the keystone for the integration of these rich multi-proxy studies in the Sarliève marsh (i.e., the radiocarbon chronology of the sedimentary sequence) was highly unsatisfactory because of uncontrolled ageing, and even after several amendments (Hatté et al., 2013), the agedepth model remained controversial due to its inconsistency with the palynological data and regional vegetation history (see Miras, 2016). This situation is especially critical between the Late Neolithic and Antiquity, because different datasets cannot be correlated, preventing any fine discussion on human-environment interactions during late Protohistory, which is considered a crucial period for the consolidation of anthropogenic impacts on natural systems (Berger et al., 2018; Mayoral, 2018). This situation is especially problematic because it affects a unique lacustrine sequence in the Limagne plain, which represents its only palynological record.

The main aim of this work was to construct an accurate and reliable radiocarbon chronology for the sedimentary infilling of the Sarliève marsh, and to use it to carry high-resolution analysis that will allow completion and refinement of the palaeoenvironmental interpretation of this reference sequence. To achieve this task, new cores drilled into the heart of the marsh were radiocarbon-dated using carefully selected materials and were subjected to multi-proxy sedimentological and geochemical analyses. These new developments are integrated, interpreted and discussed together within an accurate chronological framework provided by a Bayesian age-depth model. 

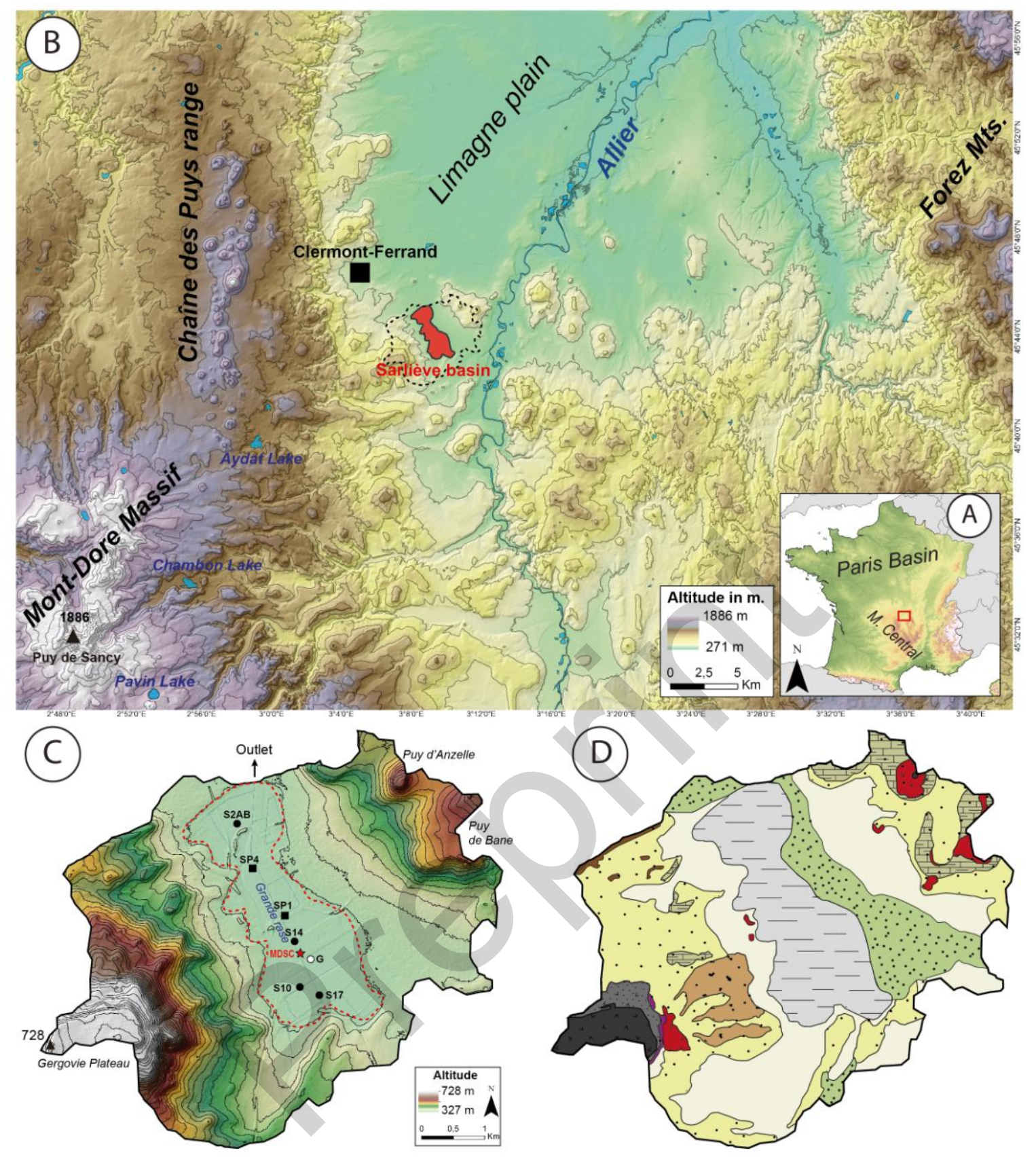

Selected sedimentary sequences

Bedrock

Surficial formations

MDSC core (this study, Dec. 2018)

- $S$ cores (A. Fourmont, 2000-2005)

- SP survey pits (INRAP, 1999-2005)

- G core (Lo. Gachon, 1963: repeated by C. Ballut, 1997)

:-... Extent of the marshy area
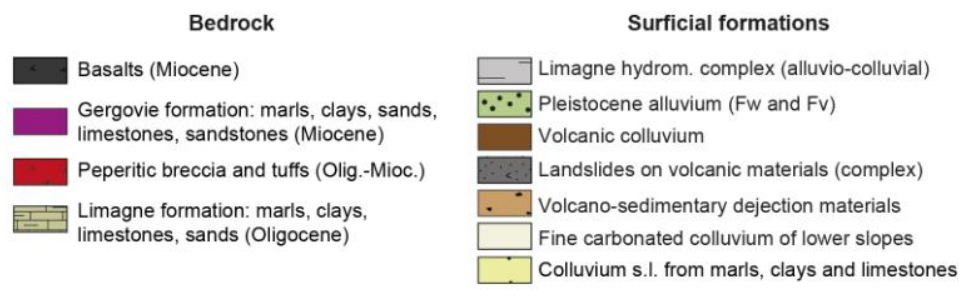

Figure 1. A) Location of the study area in central France. B) Location of the Sarliève basin in the southern 


\subsection{Coring and litho-stratigraphic description}

131

The coring was implemented in the depocenter of the southern basin of the Sarliève marsh, which offered the most dilated, complete, and representative sequence (Fourmont, 2006; Hinschberger et al., 2006; Fourmont et al., 2009). The MDS (Marais De Sarliève) cores analyzed in this study were situated between the previous cores S14 and G (see Fig. 1C). The drilling was performed in December 2018 using a geotechnical corer on tracks (tubed, 10-cm diameter) for the first $2 \mathrm{~m}$. Between $2 \mathrm{~m}$ and $5.42 \mathrm{~m}$, a light mechanical corer (Cobra TT, tubed, double cores, 5-cm diameter) was preferred, to avoid compaction of the very ductile sedimentary layers. After being opened, all cores were cleaned and photographed. A selection of the best sections of the cores was used to build the composite core Marais De Sarliève Composite (MDSC), on which all the subsequent samplings and analyses were performed. A detailed litho-stratigraphic description was performed in the laboratory.

\subsection{Dating and age-depth modeling}

Considering previous chronological issues, the materials for radiocarbon dating were inspected and selected very carefully. A part of the core between 30 and $505 \mathrm{~cm}$ was cut into $2-\mathrm{cm}$ contiguous slices, which were deflocculated in sodium hexametaphosphate and wet sieved at 500 and $100 \mu \mathrm{m}$. Both fractions were inspected using a binocular microscope ( $7.5 \times$ to $60 \times)$. Microscopic charcoals and wood or plant fragments were carefully identified with the help of a specialist to avoid aquatic macroremains and any risk of a reservoir effect. One additional dating was performed on fossil pollen extracted from the sediment, following a classical protocol (Brown et al., 1989). After careful 
mineral and organic matter) was selected for dating, which was pure enough to ensure an accurate date (Fletcher et al., 2017). In summary, 12 selected samples were sent to Beta Analytic laboratories for AMS radiocarbon dating (Table 1). Raw dates were calibrated with Calib v.810 and Intcal20 (Stuiver and Reimer, 1993; Reimer et al., 2020). A Bayesian age-depth model (BADM) encompassing all the dates was built using Bacon 3.3 (Blaauw and Christen, 2011), keeping the suggested model parameters because previous research suggested a roughly linear accumulation. The sediment accumulation rate was also calculated.

\subsection{Sedimentology \& Geochemistry}

Coarse fraction samples obtained from sieving 2-cm contiguous slices of core (see above) were examined using a binocular microscope to provide qualitative information on the nature of sediments (e.g., the presence of ostracods, seeds of Ruppia maritima, carbonated concretions, pyroclasts). Two half-sections of the MDSC where pyroclasts were identified by this inspection (452442 and $482-472 \mathrm{~cm}$ ) were cut and indurated at the EPOC Laboratory (UMR 5805, Bordeaux, F.) using synthetic resin and water-acetone replacement. Micromorphological thin sections were then produced from these blocks following a standard protocol (Guilloré, 1980). Description of the pyroclast facies was performed using a polarizing microscope, allowing a first morphoscopic characterization.

Magnetic susceptibility (MS) was measured every $0.5 \mathrm{~cm}$ using a Bartington MS2E sensor with highprecision measurements (Dearing, 1999). Sediment for grain-size analysis was sampled every $10 \mathrm{~cm}$ and pre-treated following a standard protocol (Fournier et al., 2012). However, samples were not decarbonated to avoid introduction of bias, because carbonates in Sarliève are mainly in the very fine fraction (Fourmont, 2006). Grain-size was then measured with a Malvern Mastersizer 3000 laser 
granulometer. The results were analyzed using Gradistat (Blott and Pye, 2001). Loss on Ignition was

177 used to estimate organic matter (total organic carbon; TOC) and carbonate (total inorganic carbon;

$178 \mathrm{TIC}$ ) content in a fraction of the samples used for grain-size, following a two-step protocol (4 hours at $550^{\circ} \mathrm{C}$, and 2 hours at $950^{\circ} \mathrm{C}$ ) (Heiri et al., 2001).

Geochemical analyses were performed using an Avaatech XRF Core-Scanner (UMR EDYTEM, F.).

Samples were extracted from the MDSC sequence into PVC u-channels, placed in the core-scanner, and covered with an ultrafine film (ultralene). Measurements were realized continuously between 8 and $539 \mathrm{~cm}$ with a resolution of $5 \mathrm{~mm}$. Successive runs using 10 and $30 \mathrm{kV}$ beams generated by a Rhodium anode provided the relative values (in counts per second; $\mathrm{cps}$ ) of 18 elements (Mg, Al, Si, P, $\mathrm{S}, \mathrm{K}, \mathrm{Ca}, \mathrm{Ti}, \mathrm{Mn}, \mathrm{Fe}, \mathrm{Ni}, \mathrm{Cu}, \mathrm{Zn}, \mathrm{Br}, \mathrm{Rb}, \mathrm{Sr}, \mathrm{Zr}, \mathrm{Pb}$ ). Principal component analysis (PCA) was performed on selected elements using Xlstat to assess relationships between them and the stratigraphic units (Sabatier et al., 2010; Bajard et al., 2015), and to facilitate the selection of elementary ratios as palaeoenvironmental proxies.

\section{RESULTS}

\subsection{Litho-stratigraphy of the Sarliève marsh}

A summarized litho-stratigraphic description of the MDSC sequence is presented in Table A.1 (see Appendix A). The stratigraphy is broadly consistent with those described in previous studies, especially with core S14 (Fourmont, 2006), as shown in Fig. 2. However, detailed laboratory inspection revealed new details and some particular sedimentary features (Fig. 2). Seven major stratigraphic units (SUs) were detected, including several subunits and numerous smaller layers. The texture of all the MDSC sequence is clayey and appears quite homogeneous; most differences between layers and SUs concern color and sedimentary features (e.g., laminae). 
201 SU1 $(542-519 \mathrm{~cm})$ is characterized by a beige color and a coarser texture, and has arguably been 202 assimilated to surficial deposits or weathered marly substratum in previous studies, whereas SU2 203 (519-462.5 cm) has distinctive bluish and beige colors and a finer grain-size. Its upper half (SU2B) 204 includes the first Ruppia maritima seeds in the sequence (Fig. 3E), and has been interpreted in 205 previous works as the onset of a lacustrine brackish body, maintained in overlying units (Fourmont, 2006; Fourmont et al., 2009). SU3 $(462.5-249 \mathrm{~cm})$ is the thicker unit in the sequence, and is characterized by dark clays with a very marked layering including very abundant laminae arranged in bundles (especially SU3A \& SU3B, see Figs. 2 and 3C). This SU has been interpreted as abundant detrital inputs under palustrine conditions (dark clay facies), alternating with cyclic water-restriction episodes represented by a characteristic carbonated evaporitic sequence (calcite, dolomite, aragonite) forming the laminations (Bréhéret et al., 2008). The continuous presence of Ruppia maritima indicates sustained brackish conditions in the SU. We identified a new unit, SU4 (249-177.5 $\mathrm{cm})$, which was not described in previous works. This unit is characterized by a brownish color and oxidation features, and the presence of Ruppia. SU5 $(177.5-76 \mathrm{~cm})$ is certainly the most homogeneous SU in the sequence. It consists of massive beige clays (with some slightly darker layers) of lacustrine origin, as suggested by the presence of abundant aquatic biomarkers such as characeae gyrogonites, Daphnia ephippia, and ostracods (Fig. 3A), consistent with a freshwater body (Fourmont et al., 2009). All the unit exhibits traces of very incipient pedogenesis from upper levels (small rootlets, incipient blocky subangular to angular aggregation above $100 \mathrm{~cm}$, see Fig. 2). SU6 (76-42.5 $\mathrm{cm}$ ) develops from $76 \mathrm{~cm}$, and is a grey clayey hydromorphic soil (pedogenic aggregation, mottles due to pedoturbation) that includes the "Sarliève Dark Layer" (SU6B), which is usually interpreted as a marsh and dated between the $I^{\text {st }}$ and $\mathrm{III}^{\text {rd }}$ c. AD (Vernet, 2005; Vernet et al., 2011). This layer appears manifold and disturbed by post-depositional deformation. SU7 $(42.5-0 \mathrm{~cm})$ is the current topsoil. 
Soft-sediment deformation structures (SSDS) have been detected in several sections of the core, and

226 include abundant micro-faulting of laminae, mixed layers with fragments of laminae or other layers,

227 mushroom-like structures, bottom-up intrusions of liquefied material, cusp structures, and load casts

228 (Fig. 2). These features are not due to the drilling as they appear in all cores in the same layers,

229 affecting several sedimentary facies with different properties, and were therefore interpreted as seismites (Rodríguez-Pascua et al., 2000; Monecke et al., 2006; Beck, 2009; Shanmugam, 2017). The detected SSDS features can be grouped into five seismic-affected layers (Fig. 2), four of them in SU3 $(443-398,389-380,353-314$ and 302-301 cm), and a potential fifth one affecting SU6B $(66-59 \mathrm{~cm})$. Following a common stratigraphic approach for the study of seismites in lacustrine deposits, we assumed that each one of these layers was deformed by a major seismic event, which affected unconsolidated sediments from the surface to a certain depth, and normal sedimentation resumed after each event. Therefore, the seismic events can be placed at specific depths in the MDSC sequence, i.e., at the top of each seismic-affected layer (Monecke et al., 2006; Beck, 2009; Stockhecke et al., 2014; Kremer et al., 2017).

239 


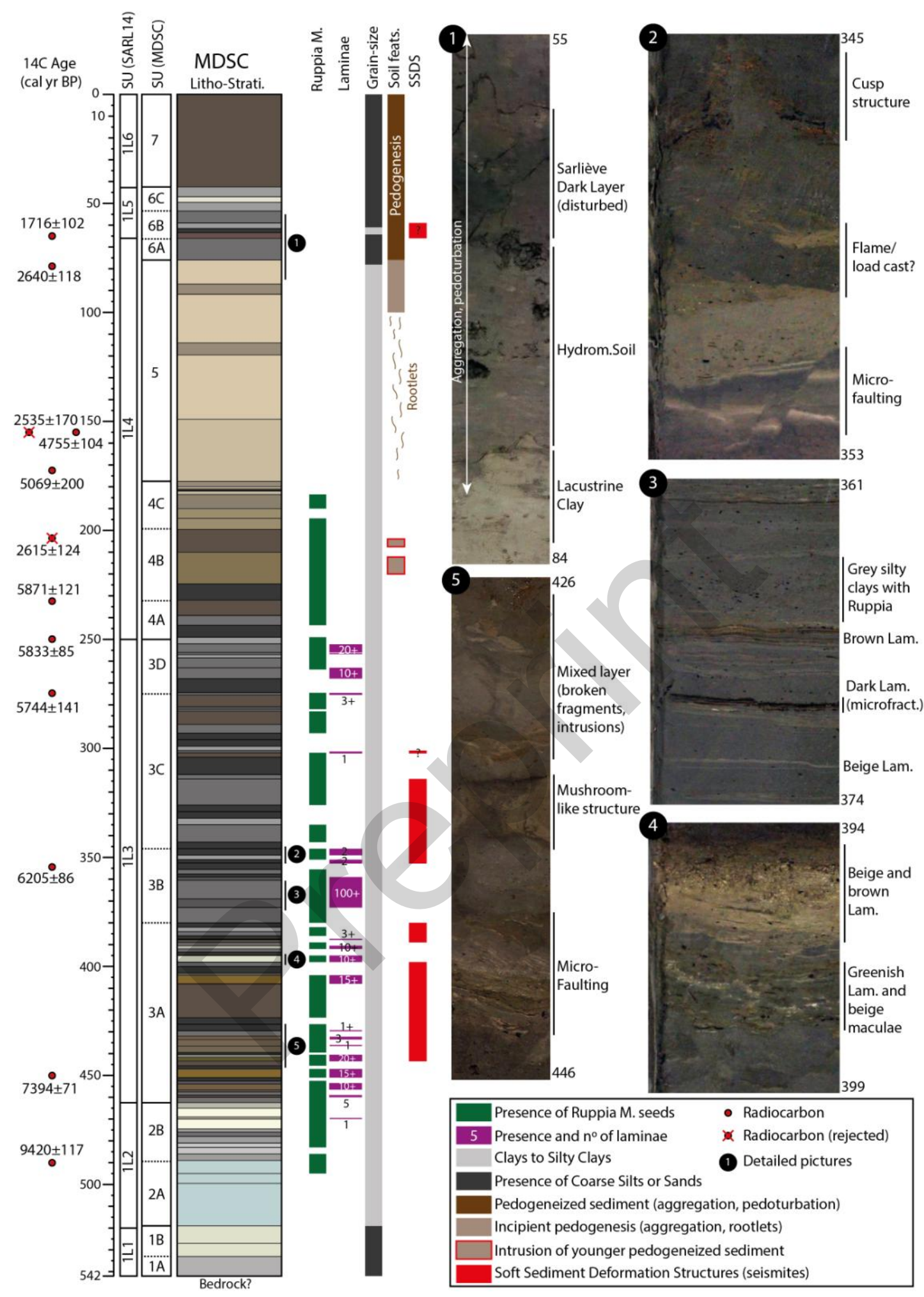

241 Figure 2. Litho-stratigraphy, main sedimentary features, and detailed pictures of the MDSC sedimentary

242 sequence ( $1-5$, note that their position in the sequence is indicated), with the location of 12 radiocarbon dates

243 (including two that were rejected). The correspondence between SARL14 (Fourmont, 2006) and MDSC (this study) stratigraphic units (SU) is indicated. 
Two intrusions of pedogeneized (aggregated) material within the massive and undisturbed sediment of SU4B were detected between 202 and $210 \mathrm{~cm}$ (Fig. 2) in the MDSC. This sediment is rich in sands and lithogenic granules, and even includes a microscopic fragment of rusty iron (anthropogenic), and can only be posterior to SU4B. These intrusions are not contaminations during the coring, as they were found at the same depth in different cores. Additionally, a "reworked" layer with very similar features was noted at exactly the same depth in previous drillings close to this point (Ballut, 2000; Fourmont, 2006), indicating that a layer with systematic post-depositional disturbance and intrusion of pedogenized material from above exists between 200 and $210 \mathrm{~cm}$ in this sector of the Sarliève basin (see Fig. 2).

Finally, sieving and systematic examination of coarse fractions of the sediment also allowed detection of three layers with high numbers of pyroclasts (Fig. 3B, D \& F) at depths of 359, 444-446, and $475-477 \mathrm{~cm}$. The pyroclasts appeared well-sorted, angular, and very sharp, and were certainly not transported by run-off. We interpreted them as (crypto)tephra fallouts in the Sarliève basin, which were hitherto unknown. A preliminary analysis of two of these fallout deposits under the polarizing microscope allowed a first characterization of their facies. Pyroclasts with a size ranging from 30 to $250 \mu \mathrm{m}$ are visible between 473.4 and $475 \mathrm{~cm}$, being dispersed in the sediment (Fig. 4A, B \& C). Between 443.7 and $445.5 \mathrm{~cm}$, pyroclastic material with a similar particle size (50 to $200 \mu \mathrm{m}$ ) forms rather an individualized dark layer (Fig. 4D \& E). These two pyroclast-containing deposits have a number of common features: most pyroclasts are angular, with few to no vesicles, and are made of black opaque glass with rare plagioclases and pyroxenes. They are typical of a "blocky morphology" characteristic of phreatomagmatic dynamics (Fisher and Schmincke, 1984; Heiken and Wohletz, 1985; Cas and Wright, 1987; Bourdier et al., 1994). In both cases, bigger (200 $\mu \mathrm{m})$ light-brownish pyroclasts made of translucent glass are less frequent. They show a pumice-like high density of vesicles (Heiken and Wohletz, 1985), and indicate more magmatic phases during the corresponding eruption (Fig. 4C \& E). The fine fraction $(>50 \mu \mathrm{m}$ ) of the $473.4-475 \mathrm{~cm}$ deposit also contains shard- 
272 shards in a glassy matrix with more or less vesicles (bubble-wall texture; Fisher, 1963) can be

273 observed (Fig. 4E). The "fresh" aspect of the pyroclasts in both deposits confirms that they are in situ

274 tephra fallouts, and their morphology points clearly to origins in eruptions with phreatomagmatic

275 phases. As the majority of the eruptions in the neighboring Chaîne des Puys have had such phases,

276 further geochemical analysis (e.g., electron microprobe) is necessary to facilitate detailed discussion

277 of the origin of these tephras.
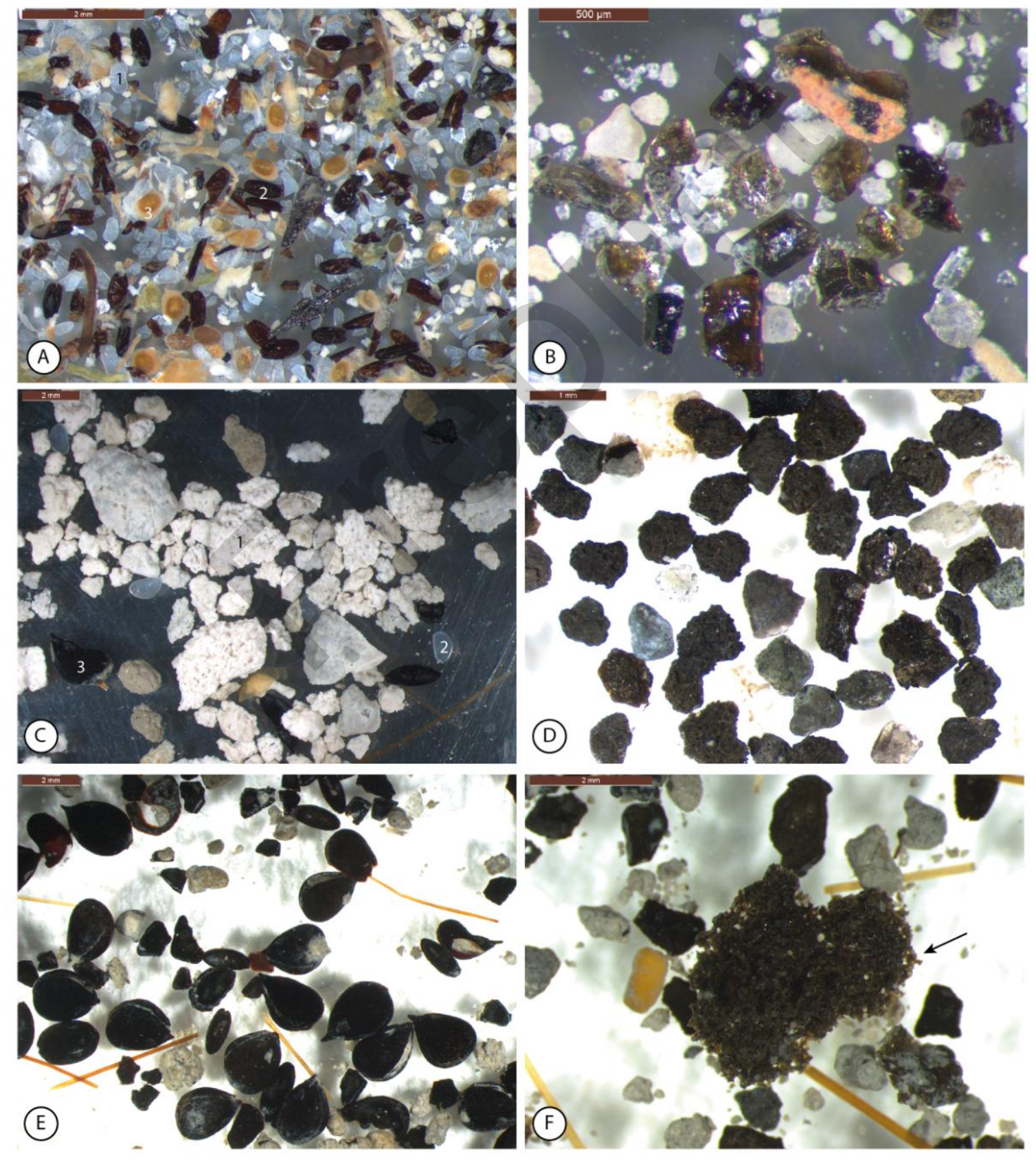

278 
Figure 3. Selected samples of the coarse fraction of the sediment (500 $\mu \mathrm{m})$ after wet sieving. A) $172-174 \mathrm{~cm}$ : markers of freshwater lacustrine conditions (ostracods [1], characeae gyrogonites [2], ephippia of Daphnia [3]), microcharcoal and organic debris; B) $359 \mathrm{~cm}$ : angular volcanic minerals, one of them embedded in reddish scoria, of pyroclastic origin; C) 394-396 cm: beige carbonated concretions from a lamination (1), a few ostracods (2), and Ruppia maritima seeds (3); D) 444-446 cm: dark, angular, and well-sorted scoriaceous pyroclasts; E) 463-465 cm: Ruppia maritima seed concentration; F) 475-477 cm: big scoriaceous pyroclast with vesicular texture and sharp edges (black arrow)
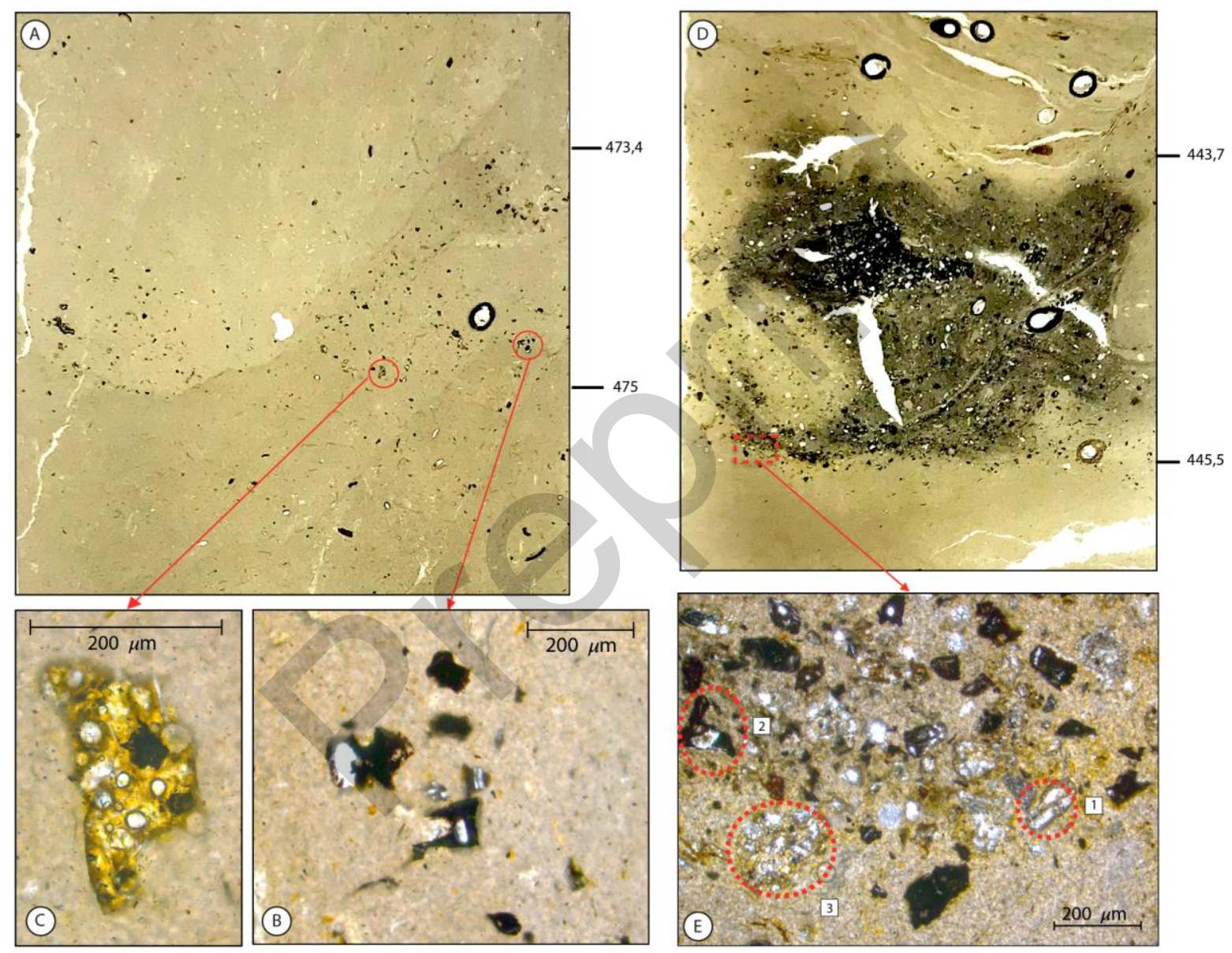

Figure 4. Macro- $(A \& D)$ and microphotographs $(B, C \& E, P P L)$ of the layers containing pyroclasts at 473.4-475 $(A, B, \& C)$ and $443.7-445.5 \mathrm{~cm}(D \& E)$ in the MDSC sequence. A) Pyroclasts dispersed in sediment; B) glassy opaque pyroclasts, angular; C) brownish glassy pyroclasts, with abundant vesicles (pumice-like); D) wellindividualized dark pyroclastic layer; E) (1) free mineral shards in a glassy gangue with more or less vesicles; (2) glassy opaque pyroclasts, angular; (3) brownish glassy pyroclasts with abundant vesicles (pumice-like). 


\subsection{Chronology and age-depth model}

The results of the radiocarbon dating are summarized in Table 1 . The dates range from $1716 \pm 102 \mathrm{cal}$ yr BP $(65 \mathrm{~cm})$ to $9420 \pm 117 \mathrm{cal}$ yr BP $(\mathrm{c} .490 \mathrm{~cm})$. All of the dated samples have $\delta^{13} \mathrm{C}$ values consistent with terrestrial materials, and therefore a reservoir effect from old carbonates is not likely. Of the 12 dates, 10 are in normal stratigraphic order. Date 6 (terrestrial plant material, 202-206 cm) is clearly outlying, as it is in marked chrono-stratigraphic inversion to the surrounding dates of samples 5 and 7 (charcoal). However, the significantly younger age of sample 6 is consistent with an intrusion of pedogenic sediment from upper levels (see above). Date 6 was therefore rejected from a stratigraphic perspective, but is considered in the discussion. The situation is slightly more complex for dates 3 (wood fragment) and 4 (pollen), which were performed on samples from the same depth $(154-156 \mathrm{~cm})$. Date 4 is consistent with dates 2 and 5; however, date 3, although not inconsistent with date 5 , is significantly younger than date 4 , and is in chronological inversion with date 2 (charcoal). Date 3 would also imply a period of very slow sedimentation rate after date 5 , followed by a quasi-instantaneous deposition of sediment between dates 2 and 3 (c. $80 \mathrm{~cm}$ of sediment), which is not consistent with the nature of the sediment (see description). Additionally, the woody material used for date 3 could be from rootlets, which are relatively abundant in this section of the core (see litho-stratigraphic description and Fig. 2). Therefore, date 3 probably represents the age of terrestrial soils from upper levels. In contrast, date 4 was performed mostly on in situ Abies pollen, which was well preserved and with no signs of reworking. On the basis of these arguments, we rejected date 3 in favour of date 4 for the $154-156 \mathrm{~cm}$ level. Remarkably, dates 2, 3, and 6 are almost the same, suggesting that they all could be due to incipient (but deep) pedogenesis phenomena (e.g., aggregation and cracking with fall of micro-aggregates, intrusion of rootlets or burrowing by microto macrofauna) related to the development of a hydromorphic soil from around $76 \mathrm{~cm}$ (i.e., circa date 2) to the current surface. 
Table 1. Radiocarbon dates from the MDSC core. Dates in italic were rejected (see the text).

\begin{tabular}{|c|c|c|c|c|c|c|c|c|c|}
\hline No. & Core & Depth $(\mathrm{cm})$ & Lab Code & Material & $\delta^{13} \mathrm{C}(0 / 00)$ & ${ }^{14} \mathrm{C}$ yr BP & Cal yr BP & $\begin{array}{c}\text { Cal yr BP } \\
\text { (median, 2б) }\end{array}$ & $\begin{array}{l}\text { Cal yr BCE/CE } \\
\text { (median, 2 } \sigma \text { ) }\end{array}$ \\
\hline 1 & MDSC & $64-66$ & Beta-526086 & Charcoal & -24.0 & $1810 \pm 30$ & 1819-1614 & $1716 \pm 102$ & $234 \pm 102 \mathrm{CE}$ \\
\hline 2 & MDSC & $78-80$ & Beta-532571 & Charcoal & -24.3 & $2580 \pm 30$ & $2758-2522$ & $2640 \pm 118$ & $690 \pm 118$ BCE \\
\hline 3 & MDSC & $154-156$ & Beta-527734 & Wood & -25.3 & $2460 \pm 30$ & $2706-2365$ & $2535 \pm 170$ & $585 \pm 170 \mathrm{BCE}$ \\
\hline 4 & MDSC & $154-156$ & Beta-546604 & Pollen & -26.0 & $4240 \pm 30$ & $4860-4651$ & $4755 \pm 104$ & $2805 \pm 104$ BCE \\
\hline 5 & MDSC & $172-174$ & Beta-536397 & Charcoal & -25.9 & $4420 \pm 30$ & 5270-4869 & $5069 \pm 200$ & $3119 \pm 200 \mathrm{BCE}$ \\
\hline 6 & MDSC & $202-206$ & Beta-532573 & Plant material & -26.4 & $2520 \pm 30$ & $2738-2493$ & $2615 \pm 124$ & $665 \pm 124 B C E$ \\
\hline 7 & MDSC & $230-234$ & Beta-536396 & Charcoal & NA & $5140 \pm 40$ & $5992-5750$ & $5871 \pm 121$ & $3921 \pm 121 \mathrm{BCE}$ \\
\hline 8 & MDSC & $249-251$ & Beta-520489 & Charcoal & NA & $5100 \pm 30$ & $5919-5748$ & $5833 \pm 85$ & $3883 \pm 85$ BCE \\
\hline 9 & MDSC & $274-276$ & Beta-532574 & Charcoal & -23.0 & $4990 \pm 30$ & 5885-5603 & $5744 \pm 141$ & $3794 \pm 141 \mathrm{BCE}$ \\
\hline 10 & MDSC & $353-355$ & Beta-526088 & Charcoal & NA & $5410 \pm 30$ & 6291-6119 & $6205 \pm 86$ & $4255 \pm 86$ BCE \\
\hline 11 & MDSC & $449-451$ & Beta-520490 & Plant material & -27.6 & $6490 \pm 30$ & \begin{tabular}{|c|}
$7465-7323$ \\
\end{tabular} & $7394 \pm 71$ & $5444 \pm 71 \mathrm{BCE}$ \\
\hline 12 & MDSC & $484-496$ & Beta-527735 & Charcoal & NA & $8440 \pm 60$ & $9538-9303$ & $9420 \pm 117$ & $7470 \pm 117 \mathrm{BCE}$ \\
\hline
\end{tabular}

319

320 All dates $(n=12)$ were used for the Bayesian age-depth modeling. The resulting BADM is presented in

321 Fig. 5, including the mean age (used for discussion), 95\% confidence interval, and accumulation rate.

322 The confidence interval ranges from 1500 years (worse, base of the core) to 100 years (best, date 9).

323 More than 15,000 stored iterations show a rather stable run with a stationary distribution. Dates 3

324 and 6 appear too young, and are bypassed by the Bayesian model, which is consistent with previous

325 assessments and reinforces the hypothesis of contamination by pedogenetic processes from upper

326 levels. The base of the model is interpolated and provides an age range of $9494-10,996$ cal yr BP

327 (mean of 10,285 cal yr BP) at $540 \mathrm{~cm}$; however, this is uncertain because the lower date (12) is

328 vertically imprecise (484-496) at the boundary between SU2A and SU2B. Therefore, the chronologies

329 of the units underlying SU2A, and especially SU1, are uncertain because a sedimentary hiatus cannot

330 be discarded. The sediment accumulation rate (SAR, see Fig. 5) is generally low at the base and the

331 top of the core (SU1-2 and SU4B-7), but rises in SU3A and 3B, and peaks strongly in SU3C and

332 SU3D/4A. 


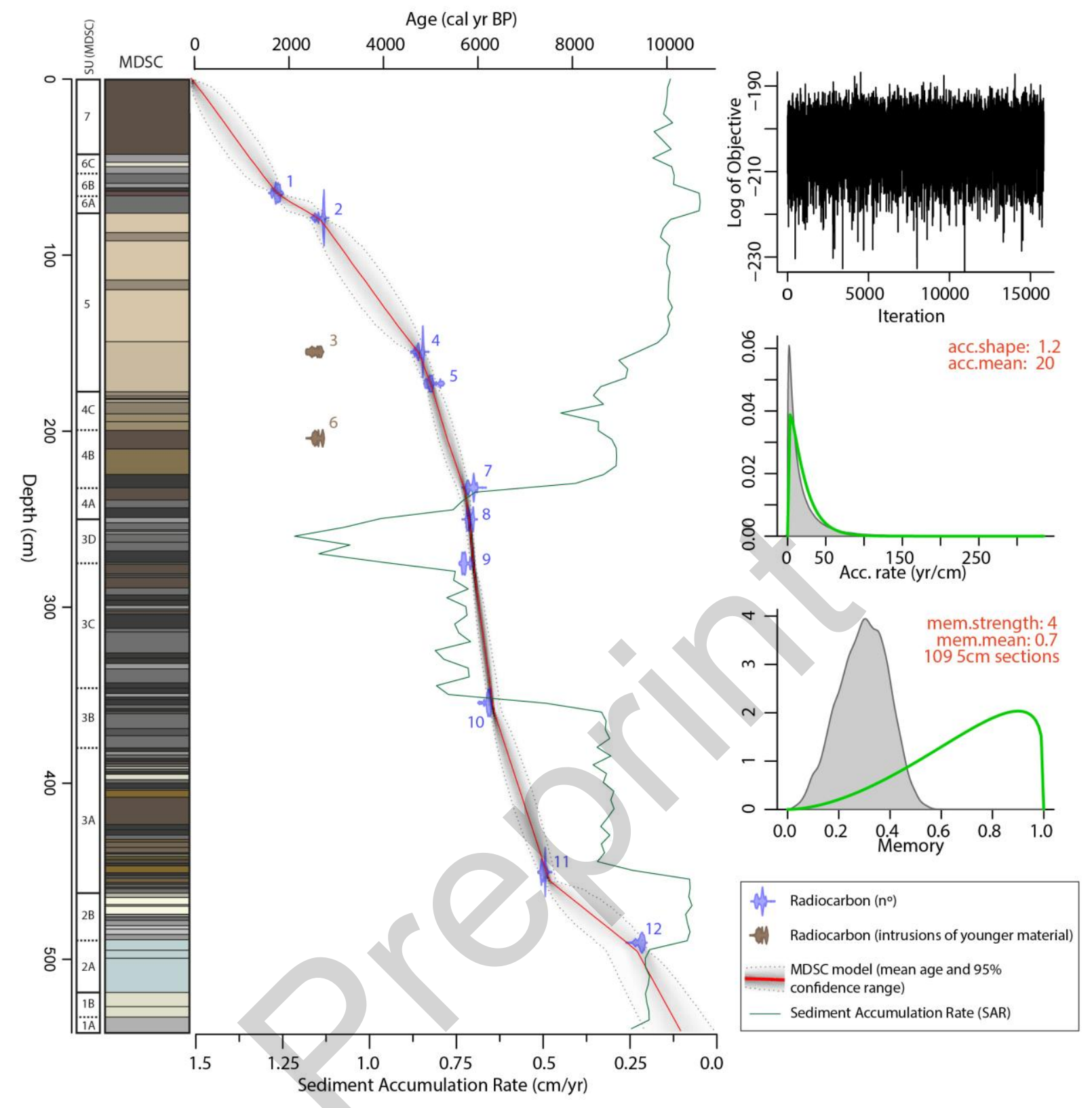

Figure 5. Bayesian age-depth model (BADM) of the MDSC sequence and sediment accumulation rate in $\mathrm{cm} /$ year, built with Bacon 3.3 using the default recommended parameters for prior distribution for accumulation rate and memory. Iterations show a rather stationary distribution. 


\subsection{Sedimentological data}

Sedimentological data for SU1-6 are summarized in Figure 6. Binocular microscope inspection of several pre-treated samples showed that besides clay and silts, there were also some fragments of ostracods and mica sheets (c. 100-300 $\mu \mathrm{m})$ and a few coarser quartz grains (>500 $\mu \mathrm{m})$.

The sediment in SU1 appears to be mainly composed of clays and fine to medium silts (main mode at 2-7 $\mu \mathrm{m}$, with a significant presence of silts and sands up to $300 \mu \mathrm{m})$. The sand content is nevertheless higher than $5 \%$, with a very high D90 and a very low D50, indicating relatively poor sorting. The unit also has the highest TIC and lowest TOC contents of the whole sequence. Taken together, these data suggest a very mineral nature to the sediment, close to natural marly bedrock, and a colluvial transport process.

SU2A is relatively similar, but with slightly lower TIC and higher TOC, and much less sands and much lower D90, suggestive of better sorting. SU2B is characterized by a slight increase in the clay content, reappearance of sands (rise of D90), and a marked decrease in TIC, while TOC peaks strongly at C. $30 \%$. However, this TOC increase is unlikely caused by a massive increase in organic carbon content, as it is not reflected at all in the sediment aspect (see description). The TOC peak in SU2B is most probably due to thermal decomposition of magnesium carbonates (Heiri et al., 2001), especially abundant in SU2 (Fourmont, 2006; Fourmont et al., 2009). Grain size diagrams show bimodal distributions in SU2, with dominant modes at $10-25 \mu \mathrm{m}$ in SU2A and 1-4 $\mu \mathrm{m}$ in SU2B (Fig. 6). Minor modes appear at c. 100 (fragments of ostracods) and $1000 \mu \mathrm{m}$ (coarse sands). The MS signal is almost flat, although a small peak at $475 \mathrm{~cm}$ coincides with the presence of pyroclasts detected during the inspection of the coarse fraction (Fig. 3F, Fig. $4 \mathrm{~A}-\mathrm{C}$ ), indicating the presence of a cryptotephra. In general, the sedimentological data suggest a change in sedimentary conditions from the opening of SU2 towards a lower energy sedimentary environment, with some higher energy 
sedimentary inputs, consistent with a small water body rich in calcium (SU2A) and magnesium (SU2B) carbonates.

The textural features of SU3 are significantly different to those of SU2: the clay content shows a sharp decay, and the sediment is largely and consistently dominated by silts (80\%-90\%). Sands become quickly negligible after the base of SU3A. D50 and D90 are very similar, indicating very good sorting, and are roughly constant in all of SU3. Grain-size diagrams are unimodal (c. 10-35 $\mu \mathrm{m}$, a small peak at approximately $160 \mu \mathrm{m}$ is due to fragments of ostracods) and virtually identical for all the samples $(n=20)$. TIC is also relatively low and constant $(10 \%-15 \%)$, with very limited fluctuations, suggesting limited carbonate inputs or precipitation. TOC falls significantly after the SU2B peak, and remains between $12 \%-15 \%$, with an upwards trend to reduction (except for SU3B, where it reaches values of c. $20 \%$, suggesting a more OM-rich wetland environment). The sedimentological data indicate a homogeneous sedimentary environment in terms of transport processes in all the SU, suggesting a very efficient sorting mechanism quasi-limited to the silt fraction, a priori alluvial or aeolian. However, in such a small catchment alluvial processes alone would not have been enough to produce that extremely good sorting. Additionnally, only anecdotal aeolian deflation processes related to modern cropping have been documented in the Limagne (Barathon and Valleix, 1993). Furthermore, the quasi absence of clays is surprising in the depocenter of a rather flat endorheic basin (Bréhéret et al., 2003; Fourmont et al., 2009; Macaire et al., 2010). This suggests that the sedimentary features of SU3 are rather inherited from a silt-sized, very homogeneous and wellsorted source of sediment, which is a priori not evident within the soils and rocks of the catchment. The MS shows at least four peaks: at 452.5 , around $441-444.5$, at 359 , and at $256.5 \mathrm{~cm}$. All are very sharp and stand out against the low background signal. Moreover, two of them (at 444.5 and 359 $\mathrm{cm}$ ) coincide with pyroclasts detected under the binocular microscope (Fig. 3B \& 3D, Fig. 4D \& E). The four MS peaks are therefore probably indicative of cryptotephra fallouts. 
The texture becomes finer again in SU4, with much more clays (40-50\%) and up to $40 \%$ fine to medium silts. This indicates a sedimentary environment with much less energy than SU3. Sands are absent in SU4A, but their content increases upwards in SU4B and 4C. D50 and D90 are lower throughout than in SU3, and have quite different trends, indicating relatively poor sorting. Grain-size diagrams show two modes at 2-4 $\mu \mathrm{m}$ and $10-30 \mu \mathrm{m}$ without any clear upwards trend, and also a small peak at $100-160 \mu \mathrm{m}$ corresponding to ostracod fragments and fine sands. TOC is maintained at about $10 \%$, and TIC increases gradually from $11 \%$ to $16 \%$ upwards, indicating more consistent precipitation of carbonates or detrital influx. MS exhibits two big peaks clearly associated with the pedogenic intrusions in SU4B (see description and Fig. 2). Although difficult to interpret from these data alone, SU4 appears similar to SU2 from a sedimentological perspective, and could therefore be consistent with a low-energy small waterbody with higher energy inputs towards the top of the unit.

Textural diagram and grain-size indicators show a very clear upwards trend to coarsening in SU5. The clay content falls through the unit from $50 \%$ at its base to c. $20 \%$ at its top, and is replaced by coarse and very coarse silts from c. $150 \mathrm{~cm}$ (from 15\% to c. 50\%), whereas fine silts and sands maintain their respective weights. D50 and D90 covary, and show the same marked trend to coarsening. A first rising phase from the base of the SU culminates in a strong peak in grain-size at c. $130 \mathrm{~cm}$. Two other peaks (c. 100 and $80 \mathrm{~cm}$ ) are separated by lower values at c. 110-120 and $90 \mathrm{~cm}$, coincident with darker layers. Grain-size diagrams clearly reflect the coarsening-upward trend, with a mode of c. 4-8 $\mu \mathrm{m}$ for samples in the lower part of SU5, shifting gradually to $20-40 \mu \mathrm{m}$ for samples in its upper part. Small peaks appear at 100-160 $\mu \mathrm{m}$ (ostracod fragments and fine sands) and above (coarser sands). TOC remains stable at around $10 \%$, whereas TIC rises slowly from 15 to $19 \%$. Sedimentological data show a clear pattern of coarser (but relatively well-sorted) sedimentary inputs in an otherwise lowenergy environment, probably lacustrine and carbonated (see description, Figs. 2 and 3). This pattern appears consistent with the increased soil erosion suggested by previous studies of this phase (Macaire et al., 2010), and growing sedimentary inputs transported by diffuse to concentrated runoff, with short phases of relatively reduced sedimentary energy. 
Textural and grain-size diagrams of SU6 indicate a composition very similar to the top of SU5, i.e., dominated by silts and coarse silts. However, the D50 and D90 show an incipient trend to grain-size reduction towards the top of the unit. TIC and TOC maintain values of c. $15 \%$ and $10 \%$ respectively. Increased and maintained MS values are consistent with the pedogenic aggregation and the pedoturbation noted in the description, and indicate soil development (Fig. 2, Table A.1). These data confirm that SU6 is the pedogenized top of SU5, with the reduction in coarser detrital inputs being probably due to a loss of sedimentary connectivity in what is now a terrestrial environment.

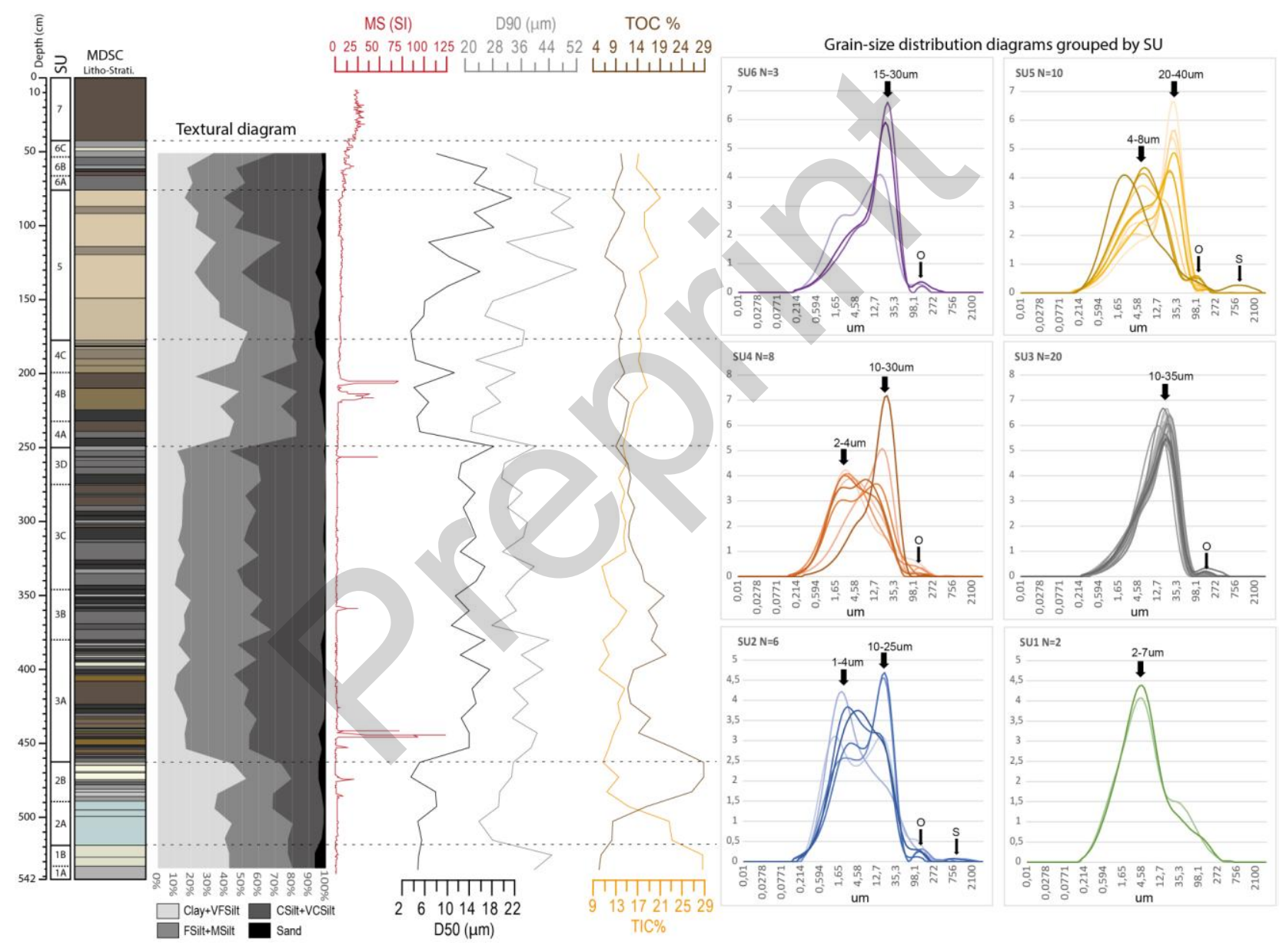

Figure 6. Selected sedimentological results of the MDSC core. Black arrows in the grain-size distribution diagrams indicate the main modes. For each diagram, the hues of the curves are lighter towards the top of the unit. MS: magnetic susceptibility (SI.10 $\left.0^{-5}\right)$, TOC: total organic carbon, TIC: total inorganic carbon, O: ostracods, S: 


\subsection{Geochemical proxies}

Results of the XRF elementary analysis are reported in Fig. 7. The PCA shows a rather well separated dataset with F1 and F2 (PC1 and 2) accounting for $54 \%$ and $15 \%$ of the variance respectively (Fig 7B). Two major clusters of elements are clearly distinguished: the first cluster groups almost all the terrigenous elements with positive loadings on F1, and a second one includes carbonate-related elements $(\mathrm{Ca}, \mathrm{Sr}$, and $\mathrm{Mg}$ ) with positive loadings on $\mathrm{F} 2$. Finally, $\mathrm{Pb}$ and $\mathrm{S}$ appear isolated and independent of the two mentioned poles.

All terrigenous elements show a roughly similar signal, and carbonate related-elements $(\mathrm{Ca}, \mathrm{Sr}, \mathrm{Mg})$ also share a common trend throughout the sequence (Fig. 7A). However, $\mathrm{S}$ and $\mathrm{Pb}$ show different behaviors with several peaks unrelated to the other elements in MDSC.

Following the positions of the different SUs in the PCA (Fig. 7B \& C) and considering their characteristics and the previous sedimentological information, we interpreted F1 as a balance between detrital and authigenic influx in the basin: higher loadings represent increased detrital inputs from the catchment, including volcanic, siliceous, carbonated, and mixed materials, whereas neutral to negative loadings are rather interpreted as dominant authigenic processes such as chemical or evaporitic precipitation during periods of low hydro-sedimentary inputs. On the basis of the available detailed geochemical characterization of the catchment (Fourmont, 2006; Fourmont et al., 2009), it appears that F2 clearly reflects geochemical sourcing: carbonates have positive loadings, whereas silicates, including minerals from felsic and mafic/volcanic rocks, have neutral and negative loadings respectively (Fig. 7B). The biplot (Fig. 7C) shows a clear geochemical progression in the MDSC sequence: SU1 and 2 are dominated by authigenic carbonates in low detrital input conditions;

450 SU3 and 4 are characterized by increased detrital inputs of rather siliciclastic and volcanic materials; and SU5 and 6 have even higher detrital contributions, with again the dominance of carbonated materials. These trends are consistent with what is known about the nature of different SUs in the 

3 , and 6).

455

On the basis of the results of the PCA, litho-stratigraphy, sedimentological data, and considering geological characteristics of the study area (see introduction), we selected several elementary ratios to use as palaeoenvironmental proxies. Previous studies demonstrated that authigenic aragonite formed during evaporitic events in the Sarliève marsh (Bréhéret et al., 2008). As Sr is more abundant in evaporitic aragonite than in other carbonate minerals (Salminen et al., 2005), the Sr/Ca ratio can here be used as a proxy of evaporitic conditions. Mn has a strong sensitivity to variability in redox conditions, specifically to dryer phases in otherwise wet environments (Kylander et al., 2011). Knowing that Fe has an opposite sensitivity, we used high values of $\mathrm{Fe} / \mathrm{Mn}$, a typical redox indicator (e.g., Cuven et al., 2011), as a proxy of change towards reducing (poorly oxygenated) conditions, including saturated soil/marsh phases (Lindbo et al., 2010). Considering the PCA distribution and the fact that volcanic materials are usually richer in Fe (Salminen et al., 2005), the Fe/Si ratio is interpreted as an overall indicator of fine volcanic sediment from the catchment (e.g., Van Daele et al., 2014). However, we propose to also use it as an indicator of basaltic cryptotephras, which should cause sharp increases in relative Fe content.

The background S signal can be interpreted as increased OM content, occurring mostly in SU3 (dark color, strong $\mathrm{H}_{2} \mathrm{~S}$ smell), and is closely related to Pyrite in continental wetland environments under anoxic conditions (Salminen et al., 2005). A minor contribution to the S signal could also come from gypsum; however, there is only marginal content in the Sarliève sediments (Fourmont, 2006). In contrast, sharp spikes are not explained by these sources; therefore, sudden increases of S can only be explained by volcanic activity. Volcanos can produce massive injections of $\mathrm{SO}_{2}$ into the atmosphere, which is detectable in sediment and ice cores (e.g., Dunbar et al., 2017; Baldini et al., 2018). We therefore propose interpreting the two unusually sharp $S$ spikes at 410 and $305 \mathrm{~cm}$ as particularly intense volcanic degassing episodes. 
The $\mathrm{Pb}$ content is poorly explained by the PCA, suggesting that it is not related to detrital or

479 authigenic minerals. Moreover, there is not a natural Pb source within the lithology of the catchment

480 (Fig. 1). Anthropogenic sources can also be discarded: the Pb peaks (515-520, 505-508, 230-250, and 180-200 cm) are older than the first traces of metallurgy in western Europe, which occurs at c. 5000 cal yr BP (Carozza et al., 2015; Martínez Cortizas et al., 2016). Additionally, the total absence of later peaks suggests that these $\mathrm{Pb}$-enrichments are more related to time-constrained events rather than to a regular source such as the catchment or human activities. The most likely source is therefore volcanic activity, which produces significant amounts of $\mathrm{Pb}$ through degassing or volcanic ash leaching (Witham et al., 2005; Kylander et al., 2010; Ayris and Delmelle, 2012). The Pb is then transported by runoff and fixed in sedimentation areas. Considering the thickness of the Pb-enriched sections of the core, long-term ash leaching seems far more plausible than punctual degassing. (see Fig. 9).

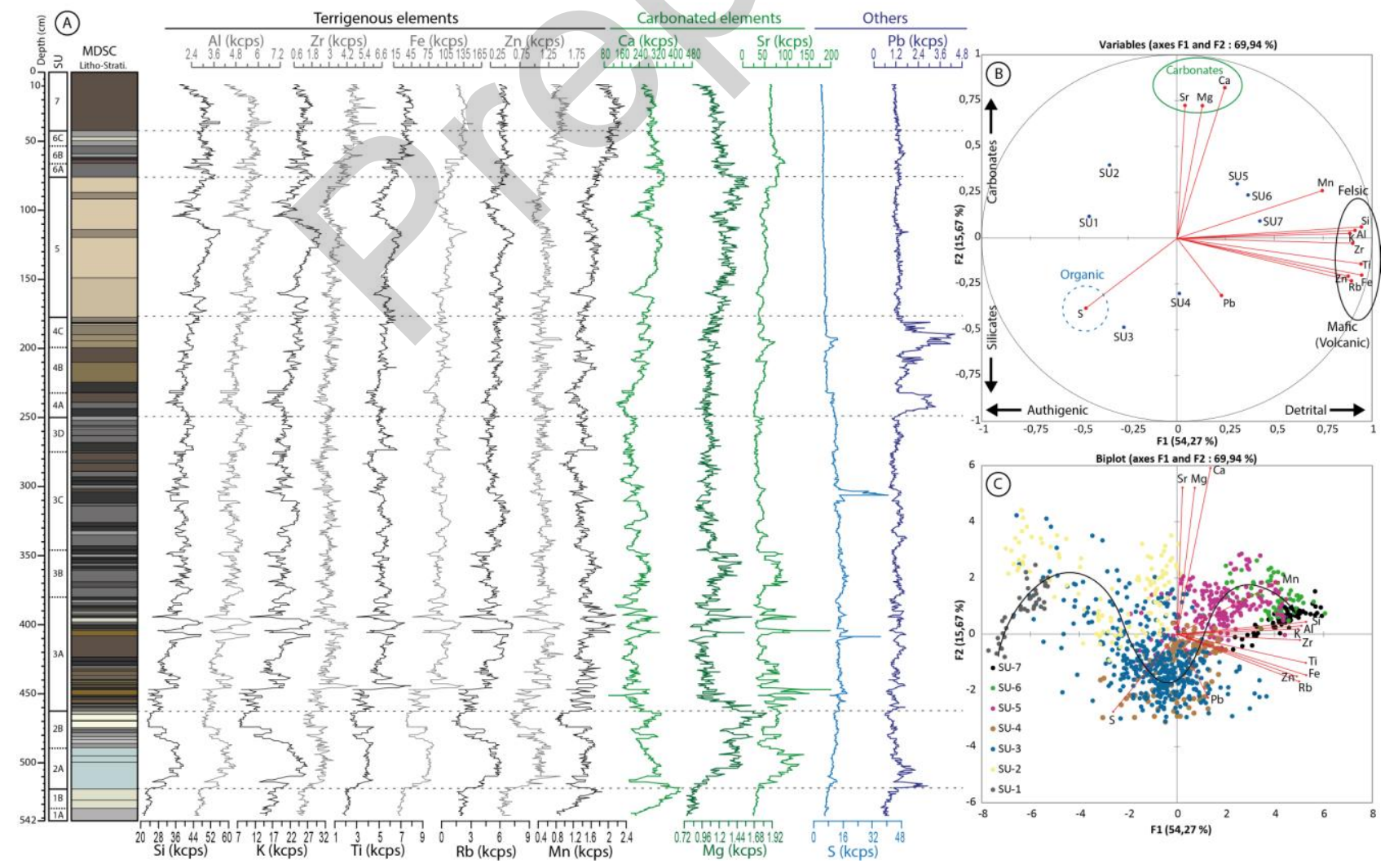


Figure 7. Selected geochemical results of the MDSC core. A) Elementary data (cps: counts per second); B) PCA correlation circle according to factors F1 and F2, with identified clusters of elements and positions of SUs; C) plot with distribution of measurements by SU (black sinusoidal arrow: global trajectory of the basin).

\section{DISCUSSION}

\subsection{Changing times: an improved chrono-stratigraphy for the Sarliève sedimentary} sequence

Three chronologies for the sedimentary infilling of the Sarliève basin were published between 2009 and 2013 (see introduction for details): the "Bulk and Ruppia" or BRM model, the "pollen-corrected estimation" - PCE - model (both in Fourmont et al., 2009), and the "lipids model" — LM (Hatté et al., 2013). From its first publication, the BRM appeared aged: the dated materials were mainly carbonated bulk sediment and Ruppia maritima seeds, introducing important and uncontrolled ageing into the age-depth model (Yansa and Long, 2007; Grimm et al., 2009). The PCE model, based on the regional palynozones, was then proposed as a younger and more reliable chronological framework (Fourmont et al., 2009). This approach implied several major inconveniences: first, the ages were only estimated; second, the palynozones were extrapolated from mountain areas of the Massif Central, although they are still unclear in the Limagne lowlands; third, it prevented an independent discussion of the chronology of the palynological data. Later works tried to rectify part of the age-depth model (only SU3) by dating lipids (Hatté et al., 2013); however, this led to a significantly younger and controversial chronology that was extremely inconsistent with the regional vegetation history (Miras, 2016). In contrast, the Bayesian age-depth model (BADM) produced in this study is based on carefully selected organic materials for radiocarbon dating, such as charcoal and 
517 which it is compared (Fig. 8).

518 The differences detected between the old models and the new more-accurate BADM proposed in 519 this work are very significant in SU3, 4 and 5 (roughly $7500-2500$ cal yr BP, see Fig. 8), with positive 520 and negative offsets up to 1000 (PCE), 1500 (BRM) and even 3000 years (LM). This implies that the 521 sequence may be subject to a substantial chronological revision and a palaeoenvironmental 522 reinterpretation, which is addressed in the following parts of the discussion.

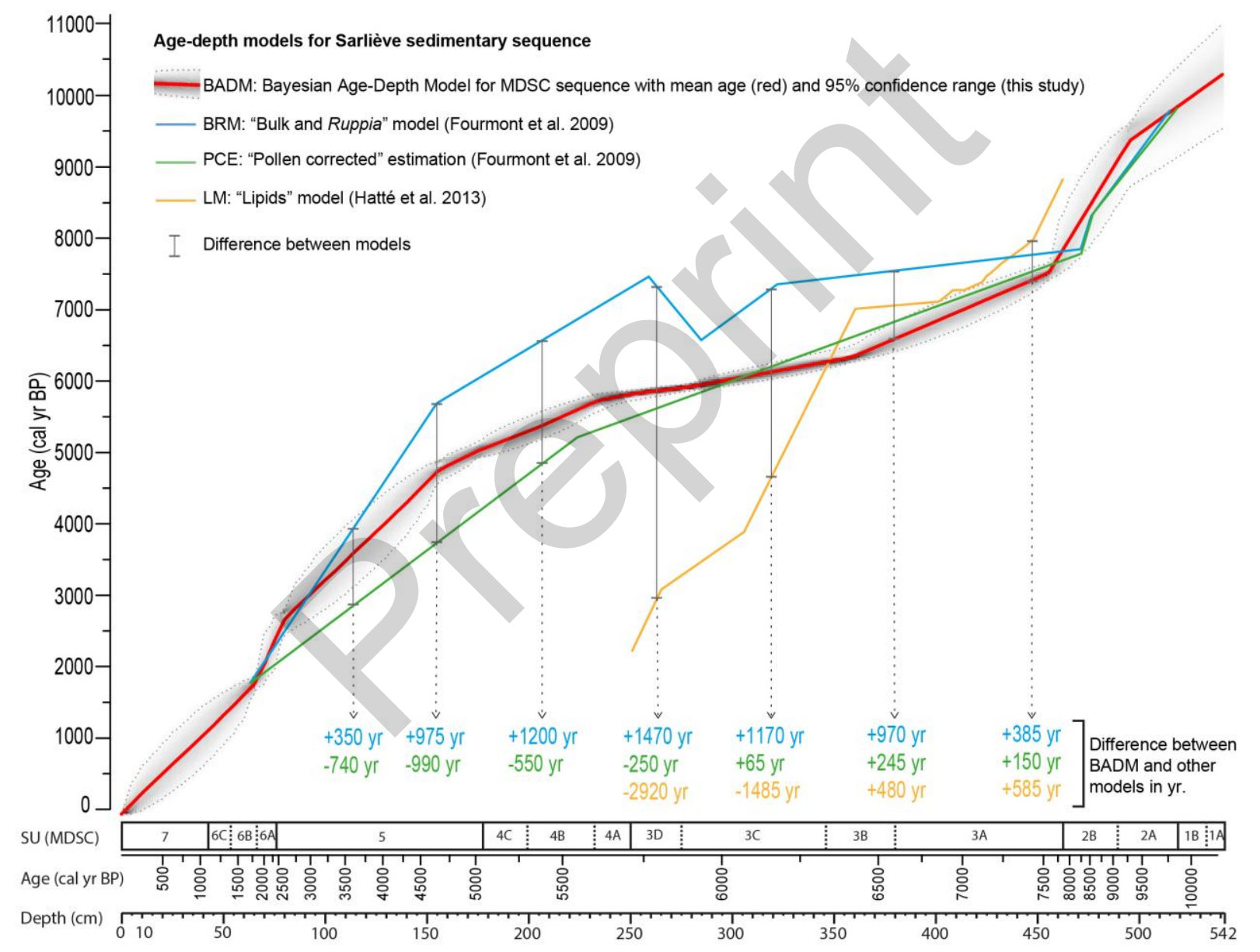




\subsection{New insights into Early and Middle Holocene volcanic phenomena}

Figure 9 summarizes sedimentological, geochemical, and litho-stratigraphic indicators of Holocene volcanic phenomena (see previous sections) recorded in the Sarliève marsh. Six potential (crypto) tephra layers ( $\mathrm{T} 1$ to $\mathrm{T6}$ ) were identified on the basis of $\mathrm{MS}, \mathrm{Fe} / \mathrm{Si}$, and the presence of pyroclasts in 500 and/or $100-\mu m$ sieve residues. Five of these tephra layers had not been detected in previous works (see introduction), highlighting the fundamental contribution of multi-proxy and high resolution analysis for detecting cryptotephras. The absence of pyroclasts when other proxies suggest the presence of tephras is not definitive, and will be checked by further studies, as particles below $100 \mu \mathrm{m}$ were not examined in this work. The presence of T1 (c. 9750 cal yr BP) is very likely, as it is marked by a major spike in Fe/Si and a small spike in S (Fig. 9). T2 (c. 8500 cal yr BP) is more tangible thanks to the presence of some pyroclasts (Fig. 3F, Fig. 4A-C) and high MS values. T3 (c. 7500 cal yr BP) is a more uncertain level, but sharp peaks in MS and Fe/Si are strongly suggestive of the presence of a cryptotephra. T4 (c. 7400 cal yr BP) is certainly the clearest volcanic fallout in the sequence, because abundant pyroclasts (Figs. 3D, 4D, \& E) coincide with strong and very sharp peaks of Fe/Si and MS. T5 (c. 6300 cal yr BP) is also supported by the presence of pyroclasts (Fig. 3B) and an MS peak. Finally, the T6 fallout (c. 5800 cal yr BP) is strongly suggested by a distinctive MS peak, but the apparent lack of other coinciding indicators means that further analysis is required for confirmation. Two degassing events are indicated by very sharp spikes in the $\mathrm{S}$ curve that are welldetached from the background signal at c. 6950 and 6050 cal yr BP.

Three major phases of increased $\mathrm{Pb} / \mathrm{Rb}$ signal can be identified in the MDSC sequence, and are interpreted as gradual $\mathrm{Pb}$ inputs from ash leaching in the catchment (see results). The first phase (AL1, 10,250-9750 cal yr BP approx.) occurs during the onset of wet conditions in the Sarliève depression (contact between SU1B and SU2A): ash leachates from older tephra fallouts (probably CF1 in the Lateglacial, not recorded in the MDSC, see introduction) probably reached the basin with 
the first hydro-sedimentary inputs. The sudden interruption of this leaching by $\mathrm{T} 1$ at c. $514-515 \mathrm{~cm}$ could be due to the modification of physico-chemical equilibriums in the soils of the catchment by this new fallout, perhaps inhibiting leaching in favour of other processes. A second phase (8500-7400 cal yr BP approx.) is bracketed by tephras T2 and T4, and can be subdivided into two episodes of more marked ash leaching ( $\mathrm{AL2}$ and 3 ) separated by relatively lower $\mathrm{Pb} / \mathrm{Rb}$ values. AL2 shows a particularly strong leaching signal just after $\mathrm{T} 2$, suggesting that its $\mathrm{Pb}$ content could have been massively leached and reached the basin in the centuries following the fallout. AL3 shows a succession of smaller peaks, indicating renewed but less intense leachate inputs from the previous fallout after a short period of reduced leaching around $7800-8000 \mathrm{cal}$ yr BP. The end of AL3 coincides with T3, and especially with T4, suggesting that these new fallouts could have interrupted leaching in favour of other processes, such as in $\mathrm{T} 1$ (see above). The third phase of Pb enrichment in the sequence (5800-5100 cal yr BP approx.) is also divided into two distinct events, AL4 and AL5. The first one is a marked narrow peak (5800-5700 cal yr BP=) just following T6, indicating immediate leaching of $\mathrm{Pb}$ from the fallout. AL5 is a larger peak (5400-5100 cal yr BP.) unassociated with any tephra; it could represent a renewal of T6 leaching due to wetter conditions after the mid-Holocene climatic shift (Steig, 1999; Fletcher et al., 2013; Zielhofer et al., 2019), or even an unknown fallout c. 5250 cal yr BP.

Five episodes of high seismic activity (earthquakes) were identified from SSDS layers (see results). Earthquakes (EQ) 1 and 2 occurred circa 6800 and $6600 \mathrm{cal}$ yr BP respectively. EQ3 and 4 were very close in time, at around 6050-6100 cal yr BP. The sedimentary signature of EQ4 is uncertain, but the event is remarkably coincident with a degassing event (see before). EQ5 affected the Sarliève Dark Layer, but from the litho-stratigraphic description, it is unclear whether it occurred around $1600 \mathrm{cal}$ yr BP or a few centuries after, because the upper boundary of the disturbed layers cannot be properly identified because of pedoturbation phenomena. 
577 A clear phasing emerges from the chronological distribution of all these volcanic phenomena 578 recorded in the MDSC from the Early and Middle Holocene. Three phases of secondary impacts of

579 volcanism (gradual leaching of previous fallouts in the catchment) surround a high volcanic activity 580 phase between 7500 and $5800 \mathrm{cal} \mathrm{yr} \mathrm{BP}$, identified for the first time in the region. This phase, 581 corresponding roughly to SU3, includes four episodes of volcanic fallout (T3 to T6), and almost all the 582 detected seismic and degassing events. Its chronology is not out of place, as Mid-Holocene volcanic 583 activity is documented in the Chaîne des Puys and the neighboring Cézallier (Fourmont et al., 2006;

584 Boivin et al., 2017), and is deserving of dedicated investigations at a larger scale in the future. 


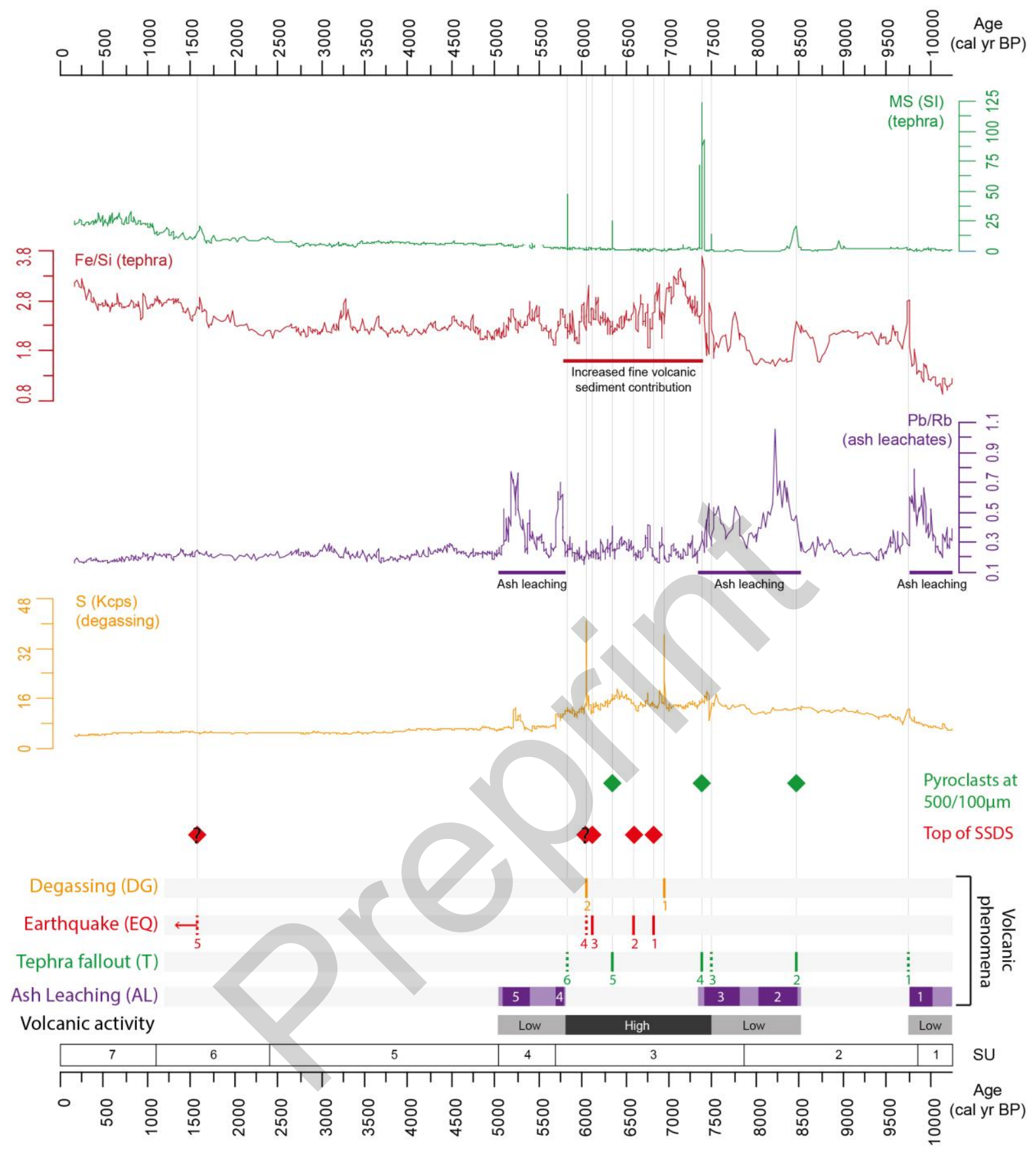

Figure 9. Sedimentological, chemical, and litho-stratigraphic indicators of volcanic phenomena in the MDSC are numbered in chronological order. Less certain events are marked with "?", or dashed lines. Purple hue reflects the intensity of ash leaching from soils of the catchment. MS: magnetic susceptibility $\left(\right.$ SI.10 $\left.{ }^{-5}\right)$, SSDS: soft-sediment deformation structures. 
593 tephrostratigraphy, and palaeoseismology, to assess possible correlations. The proposed

594 chronological assemblage in Fig. 10 constitutes a first approach, and is subject to future refinements, 595 awaiting the forthcoming detailed physico-chemical analysis of the new tephra layers. Events 596 detected in the Early Holocene and at the beginning of the Middle Holocene (before 7500 cal yr BP, AL1-3 and T1-2, see Fig. 10) are difficult to match with the volcanic chronology because of the abundance of eruptions (most of them poorly dated) and the relatively low precision of the BADM in lower parts of the core. After $7500 \mathrm{cal} \mathrm{yr} \mathrm{BP,} \mathrm{the} \mathrm{correlations} \mathrm{are} \mathrm{more} \mathrm{certain} \mathrm{because} \mathrm{of} \mathrm{less}$ volcanic eruptions and more accurate chronologies. $\mathrm{T} 3$, and especially $\mathrm{T} 4$, are probably related to the tephra of the Pavin maar (Juvigné and Gilot, 1986; Boivin et al., 2011), and T5 is almost certainly the G1/M1 tephra recently detected in the nearby Forez range (Jouannic et al., 2014).

603

604

605

606

Correlations between T6, AL4, and AL5, and the "Tephra de Sarliève" and the "Tephra de Beaunit" (Fig. 10), are less straightforward, and interpretations are subject to caution. These two chemically different tephras are very close in time and not well dated (Juvigné et al., 1986; Vernet, 2005; Fourmont et al., 2006; Vernet et al., 2011). A first examination of the chronological structure of the events suggests that T6 could be the "Tephra de Beaunit", and AL4 the subsequent ash leaching episode. In this case, the "Tephra de Sarliève" would not have been directly detected in the MDSC core, but its leaching would correspond to AL5. However, the accepted date of c. 5400 cal yr BP for the Tephra de Sarliève (Fig. 10, Fourmont et al., 2006) is in fact based on the PCE chronology, which we consider to be under-aged by c. 400 years at this point (Fig. 8). Therefore, we believe the true age of this tephra following the BADM is c. $5800 \mathrm{cal}$ yr BP, i.e., almost the same as the "Beaunit Tephra" and T6. This complex situation will only be disentangled by a detailed comparative analysis of the involved tephra layers in the forthcoming years.

Two clusters of degassing events associated with earthquakes are also evident between 7000 and 6000 cal yr BP (Fig. 10), suggesting that the earthquakes were caused by volcanic rather than tectonic 
617 activity. The first cluster (DG1 and EQ1-2, 7000-6500 cal yr BP approx.) seems quite clearly related

618 with three highly-explosive eruptions very close in time (Pavin, Montchal-Estivadoux, and 619 Montcineyre, see Juvigné and Gilot, 1986; Boivin et al., 2011, 2017). The association of the second 620 cluster (DG2 and EQ3-4, c. 6200-6000 cal yr BP) with volcanic activity related to the fallout of the 621 "Tephra de Beaunit" is unclear, especially considering the chronological uncertainty. Finally, a single 622 earthquake (EQ5) in historical times could be related to at least three earthquakes detected in 623 different wetlands and volcanic lakes in the surrounding region during the first centuries of our era 624 (Fig. 10, see Lavrieux et al., 2013; Vernet, 2013; Chapron et al., 2018), including one affecting the 625 Sarliève marsh, which seems the most plausible (Vernet et al., 2011). 
Local volcanic chronology;

Tephrochronology;

Volcanic phenomena

Palaeosismology

Tazenat, Pavin

[Chapron et al. 2018] $\times$

Gravanches

[Vernet, 2013]

Aydat, Sarliève

[Vernet, 2011,

Lavrieux et al 2013]

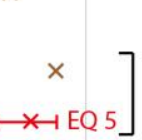

Sarliève [Vernet, 2005; Fourmont et al., 2006; Vernet, 2011]

Beaunit [Juvigné et al., 1986]

G1/M1 [Jouannic, 2015]

Pavin (eruption) [Boivin et al, 2012]

Montchal-Estivadoux [Juvigné and Gilot; 1986; Boivin et al. 2017]

Montcineyre [Juvigné and Gilot; 1986; Boivin et al. 2017]

Pavin (tephra) [Juvigné and Gilot; 1986, Boivin et al, 2012]

La Vache [Boivin et al. 2017]

CF7 (Kilian) [Vernet, 2011]

CF6 (Pariou) [Vernet, 2011, 2013]

CF5 (Vasset) [Vernet 2011]

Kilian (eruption) [Boivin et al. 2017]

Puy Vasset (eruption) [Miallier et al., 2004]

Nid de la Poule [Boivin et al. 2017]

FdM (Chopine) [Vernet, 2011]

Chopine (eruption) [Boivin et al. 2017]

Pariou (eruption) [Boivin et al., 2017]

\begin{tabular}{|c|c|c|c|}
\hline 7 & 6 & 5 & 4 \\
\hline
\end{tabular}

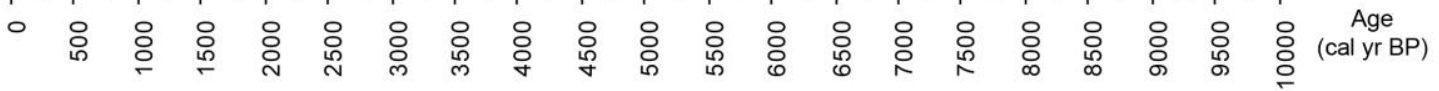

Figure 10. Comparisons of volcanic phenomena recorded in the MDSC core with local volcanic chronology, tephrochronology, and palaeoseismology. References are given in brackets. Dates are plotted with their known age uncertainties (from literature or from BADM). When the latter are lacking, ages are plotted with a default uncertainty of \pm 500 years (dashed lines). AL events are plotted as an interval, with the uncertainties of their extremes. Black brackets indicate possible clusters of associated phenomena/events. 
The new analytical data and the accurate chronological framework allow us to propose a renewed interpretation of the Holocene hydro-sedimentary history of the basin, and to reassess the weight of climatic, anthropogenic, and volcanic drivers (Fig. 11).

638

The distinctive characteristics of the base of the sequence (SU1, before $9800 \mathrm{cal}$ yr BP, although the BADM is imprecise here) suggest a highly mineral, authigenic, and very well-oxygenated carbonated environment, rich in fine particles with some coarser inputs (see results and Fig. 11). These features are highly congruent with a marly substratum reworked by colluvial processes, as proposed in previous works (Fourmont, 2006; Fourmont et al., 2009), and probably dating to the cold phases of the very Early Holocene (Preboreal) or even the Lateglacial, although no date supports this chronology.

646

The overall palaeoenvironmental picture for SU2A and B (9800-7800 cal yr BP) is also broadly consistent with previous works (Bréhéret et al., 2008; Fourmont et al., 2009; Macaire et al., 2010), despite small chronological differences. The onset of aquatic conditions in the basin seems to occur carbonated lake, likely endorheic, with formation of authigenic carbonates. The high values of $\mathrm{Si}, \mathrm{Al}$, $\mathrm{K}, \mathrm{Fe}, \mathrm{Rb}$, and $\mathrm{Zn}$ (see Fig. 7) in a general context of reduced detrital inputs suggest a small and extremely mineral waterbody with a high dissolved load, consistent with the absence of Ruppia maritima. This mineral enrichment could be due to dissolved products from Lateglacial volcanic fallouts (Fourmont et al., 2006), but also to seepages from mineral springs, which are locally very common in depressed areas controlled by faults such as the Sarliève basin (Ballut, 2000), and could have represented a significant contribution to this first lake. Around $9100 \mathrm{cal}$ yr BP, these conditions change to those of a more permanent waterbody, indicating slightly wetter conditions than those of 
previous periods, although still with evaporitic phases (SU2B, Fig. 11). The first apparition of Ruppia maritima, fragments of ostracods (Fig. 6), and a much finer sedimentary matrix, suggest more abundant and permanent saline waters (pre-evaporitic?) with some detrital inputs (presence of sands). Authigenic carbonate formation in this playa-like salt lake seems to have been dominated by high-Mg calcite or dolomite (see sedimentological data), as suggested by other authors (Bréhéret et al., 2008; Fourmont et al., 2009).

The beginning of SU3 (c. $7800 \mathrm{cal}$ yr BP) is characterized by the onset of irregular hydrological conditions in the basin, as suggested by the apparition of the first bundles of laminae (Bréhéret et al., 2008; Fourmont et al., 2009). Otherwise, carbonated sedimentation is markedly evaporitic and the waterbody is brackish (presence of Ruppia maritima, Fig. 11). The period between 7400 and 6300 cal yr BP approx. is characterized by a totally different sedimentary environment and highly changing hydrological conditions, alternating between evaporitic and marshy phases $(\mathrm{Sr} / \mathrm{Ca}, \mathrm{Fe} / \mathrm{Mn}$, abundance of laminae). The sediment accumulation rate increases, as does the D50, indicating more abundant and higher energy detrital inputs dominated by silts (Fig. 6). Evaporitic phases are rather characterized by deposition of authigenic carbonates in laminations (for details see Bréhéret et al., 2008), whereas marshy phases feature siliceous sedimentation (Fig. 11), mainly detrital silts, but certainly also some authigenic silicates such as quartz, feldspar, zeolites, and smectites (Fourmont, 2006; Fourmont et al., 2009). Between 6300 and 5700 cal yr BP, hydrological conditions remain similar, but become gradually wetter and more stable with predominantly marshy conditions (few laminations) and very short and weak evaporitic phases, probably due to wetter conditions during the recent Atlantic period. The accumulation rate reaches extreme values (above $1 \mathrm{~cm} / \mathrm{year}$ ) by the end of the phase. The particular sedimentological and geochemical features between $7400-5700 \mathrm{cal}$ yr BP are suggestive of a forcing of the hydro-sedimentary system, which caused massive and quick inputs of silty siliceous sediments (or dissolved siliceous load) into the basin. 
These findings are in general agreement with those of previous research works, which proposed that the development of agricultural activities during the first phases of neolithization c. $7400 \mathrm{cal}$ yr BP could have caused significant soil erosion and exceptionally quick accumulation rates in the Sarliève marsh from the beginning of SU3.

However, these interpretations are undermined by a number of significant flaws: first, an anthropogenic cause for this dramatically increased sediment supply to the basin is not clearly established in sediment yield studies (Macaire et al., 2010). Second, only very weak evidence of Early Neolithic occupations (two sherds dating to the end of the Early Neolithic, i.e., before c. $6500 \mathrm{yr}$ BP) have been detected by archaeological prospection in the catchment (Trément et al., 2007). Moreover, agricultural developments during such an early period were rather limited (Delpuech, 1987), and increases in soil erosion were very local (Mayoral, 2018; Mayoral et al., 2020a). In summary, these considerations suggest that the local small Early Neolithic communities are unlikely to have caused such a strong sudden catchment-scale (c. $30 \mathrm{~km}^{2}$ ) impact on soil erosion at Sarliève since 7400 cal yr BP.

The results of the work described in this study suggest an alternative and more complex scenario for the deposition of SU3 between 7400 and $5700 \mathrm{cal}$ yr BP. The unit has very specific features that are not repeated in any of the other detrital phases during later periods. The markedly siliceous and volcanic nature of the fine sediment (low F2, high Fe/Si, see Figs. 9 and 11), contrasting with the carbonated nature of the catchment and with an absence of granitoids or sandstones, points to a source in siliceous volcanic materials. Geochemical analysis in the catchment (Fourmont, 2006; Fourmont et al., 2009) showed that some samples of SU3 had a composition close to that of the volcanic rocks of the catchment, especially the tephras. Additionally, sedimentological data (see results) indicate either a very well-sorted and homogeneous silty source material instead of generic soil erosion, or a silt-focused transport process (such as aeolian transport), or both. Finally, the extremely high accumulation rate suggests a temporarily very abundant and available sedimentary 
source. Finally, the chronology of SU3 coincides remarkably well with the detected cluster of intense volcanic activity between 7400 and $5800 \mathrm{cal}$ yr BP (see above), which includes four potential tephra layers (T3 to T6, Fig. 10).

Therefore, SU3 can be only interpreted as the result of local to micro-regional production of massive quantities of very fine volcanic ash (silt-sized, extremely well sorted and rich in $\mathrm{Si}, \mathrm{Al}$ or $\mathrm{Fe}$ ) by sudden and intense volcanic activity from c. 7400 until 5800 cal yr BP. Unconsolidated volcanic ash and dust deposits (from one or several rhyolitic or trachyandesitic eruptions) would have been completely removed from the catchment, mainly by aeolian deflation, but secondarily by runoff and dissolution, and would be finally trapped in the Sarliève basin, which was endorheic by this time (Fourmont et al., 2009). The deposits accumulated quickly, forming a thick layer of well-sorted fine siliceous material mixed with minor amounts of detrital materials from soil erosion and authigenic carbonates. The formation of authigenic silicates occurred probably from the dissolution of the ashes in the brackish water, or from high inputs of dissolved Si from ashes in the catchment, as suggested by Fourmont (Fourmont, 2006; Fourmont et al., 2006; Fourmont et al., 2009). All these processes, in combination with the gradually wetter conditions detected after $6300 \mathrm{cal}$ yr BP, are the likely causes of the exceptionally high accumulation rates of well-sorted silty silicates in the basin between 7400 and 5600 cal yr BP (Fig. 5 \& 11), with a paroxysm at c. 5800-5700 cal yr BP (peak of SAR coincident with the T6 fallout). This volcanic forcing of the hydro-sedimentary system during the Middle Holocene at Sarliève questions the classical morpho-sedimentary narrative in the Limagne lowlands, i.e., that of increased erosion and floodplain aggradation due to volcanic activity in the Lateglacial and Early Holocene, followed by rather low-energy dynamics in the Mid-Holocene (Ballut, 2000; Vernet and Raynal, 2002; Raynal et al., 2003). The comprehensive understanding of interactions between volcanos, climate, and humans during this period is a complex challenge that is beyond the scope of this work and will require further multidisciplinary studies. 
These dynamics changed abruptly from the beginning of SU4; during the phase between 5700 and 5000 cal yr BP, the hydrological conditions were permanently marshy and brackish with few weak evaporitic phases (presence of Ruppia maritima but absence of laminations). The sedimentary accumulation rate falls quickly, as does the D50, indicating much less and weaker sedimentary inputs, although the siliceous fraction is still dominant at the beginning of the phase. The main reason for this marked sedimentary slowdown is probably the end of the intensive volcanic activity and volcanic ash inputs after 5800 cal yr BP (Fig. 9). However, less important archaeological occupations and reduced anthropogenic pressure on soils during the beginning of the Late Neolithic (Trément et al., 2007; Macaire et al., 2010) could also have contributed. From a grain-size and textural perspective, this phase is very similar to SU2, suggesting a relative recovery of previous sedimentary processes after the forcing represented by SU3 (Fig. 6), although under clearly wetter conditions since approximately $6300 \mathrm{cal}$ yr BP. This phase was nevertheless transitory, as a new detrital signal emerged and grew gradually from c. 5500 cal yr BP (Fig. 11).

This detrital signal increases steadily during the next phase (SU5, 5000-2500 cal yr BP approx.), while the water level continued to rise. The sedimentary environment of SU5 was probably that of a permanent freshwater carbonated lake (absence of Ruppia maritima and laminations, lacustrine clay facies with an abundance of ostracods, Characeae gyrogonites, and Daphnia ephippia), consistent with the interpretations proposed in previous work (Bréhéret et al., 2008; Fourmont et al., 2009 i.a.). A rise of the outlet level (perhaps due to a mudflow, see Fourmont, 2006) combined with wetter conditions after the Mid-Holocene hydroclimatic shift would have led to an increase in the water level and the connection of both sub-basins.

During the first phase (5000-3600 cal yr BP approx.) of the lake at Sarliève, the accretion rate remains very low, but the relative detrital influx becomes gradually stronger, reaching a peak at $\mathrm{c}$. 3700-3600 cal yr BP. The D50 signal, despite its relatively low resolution, indicates an increase in the 
energy of the detrital inputs, suggesting more concentrated runoff. Forcing of soil erosion by Late Neolithic societies seems plausible here from 5000 , or perhaps 5500 cal yr BP, in agreement with the marked increase in the intensity of erosion and in the sedimentary yield that previous works interpreted as anthropogenic at Sarliève (Macaire et al., 2010), but also with other lacustrine records in the Massif Central with roughly similar chronologies (e.g. Martin et al., 2019). Remarkably, this is rather a phase of site abandonment and reduced erosion in the neighboring volcanic plateaus of the Limagne (Mayoral et al., 2020a), suggesting that settlements could have moved to the lowlands. Between 3600 and $2500 \mathrm{cal}$ yr BP (following the BADM) the picture becomes more complex: just after 3600 cal yr BP the detrital influx and the D50 fall abruptly, indicating less erosion in the catchment. This situation is maintained until approximately 3000 cal yr BP, when both indicators rise again and maintain high values until c. $2500 \mathrm{cal}$ yr BP. This phase of reduced erosion and detrital inputs coincides with the Middle Bronze age and the first part of the Late Bronze age, two cultural periods poorly known at local and regional scales because of a marked lack of remains, but characterized by abandonment of previous habitats and a reduced number of settlements compared with the Early Bronze age and the end of the Late Bronze age (Trément et al., 2007; Couderc, 2019). It is therefore likely that less human impacts during this phase were the reason for the significant reduction in soil erosion and detrital inputs into the basin, followed by a recovery by the end of the Late Bronze age, as noted elsewhere in Limagne (e.g. Mayoral et al., 2020b).

Several short-lived lacustrine low-stands have been detected in SU5 from stratigraphy and geochemical proxies (Fig. 11), most of them concentrated in the Middle and Late Bronze age. The water level in the carbonated lake was lower at c. 4750-4600, 3750-3600, 3350-3200, and 29502800 cal yr BP, indicating comparatively dryer periods. All of these are synchronous with welldocumented phases of low levels in western alpine lakes and dryer pedogenic phases in the Rhône valley (Magny, 2004; Berger et al., 2007; Magny et al., 2007), pointing clearly to climatic control. In general, these dryer phases are associated with favourable periods for expansion of human activities in northern alpine Europe (Tinner et al., 2003). However, at Sarliève, a positive or negative 
correlation with anthropogenic impacts in the catchment is not evident, suggesting that the local influence of these otherwise small climatic oscillations on Late Neolithic and Bronze Age societies was limited.

The carbonated lake represented by SU5 disappears abruptly and leaves in place SU6 at a depth of 76 $\mathrm{cm}$. This unit (and also the current soil SU7) is in general terms a relatively dry hydromorphic soil, with some phases of carbonated marsh. It is marked by a strong detrital influx due to the erosion of the catchment, but the low accretion rate and the decreased D50 also suggest reduced hydrosedimentary connectivity, nowadays maintained by a dense network of drainage ditches (Fig. 1C). The sharp transition between SU5 and SU6A, interpreted as a lake drainage phase (as the core is situated in its deepest part), is dated in the BADM to c. $2400 \pm 330$ cal yr BP. However, this date can be refined using radiocarbon 3 and $6(2535 \pm 170$ and $2615 \pm 124$ cal yr BP respectively, see Table 1$)$, which are also considered in the dating of this event (see results), and suggest that the drainage occurred between 2500 and 2600 cal yr BP approx. Date number 2 (2640 \pm 118 cal yr BP) at $79 \mathrm{~cm} \mathrm{(3}$ $\mathrm{cm}$ below the top of SU5) also supports this chronological interpretation, as the accretion rate in this section of the core is $0.125 \mathrm{~cm} /$ year (i.e., 8 years $/ \mathrm{cm}$ ). This precocious date for the drainage of the lake is earlier than the chronology proposed by previous works (c. 2250 cal yr BP, Trément et al., 2007; Macaire et al., 2010). A very similar date (c. 2600 cal yr BP) was recently proposed for the drainage of la Narse de la Sauvetat, a similar although smaller wetland $8 \mathrm{~km}$ south of the Sarliève marsh (Mayoral et al., 2018; Mayoral et al., 2020b), revealing a pattern of wetland drainage in Limagne at the beginning of the second part of the first Iron Age. This chronology presumes that the Hallstatt societies possessed significant hydraulic capacity and were able to drain and settle former wetlands, as already detected in other French regions (Milcent and Mennessier-Jouannet, 2007; Bernigaud et al., 2014; Riquier et al., 2015).

\section{This drainage led to the development of a hydromorphic soil (SU6A, see Fig. 2) characterized by a} reduction in detrital inputs, a less-carbonated mineralogy, and a shift towards a slightly evaporitic 
regime (F1, F2, Sr/Ca in Fig. 11). The presence of this soil between the drainage of c. $2550 \mathrm{cal}$ yr BP

815 and the development of marshy conditions in Roman times (see below) fills a supposed hiatus of

816 several centuries (Fourmont et al., 2009; Macaire et al., 2010), opening room for the study of the

817 Iron Age in the sequence, which is a major period of anthropogenic impact in Limagne (Trément et

818 al., 2007; Mayoral, 2018). The sudden onset of marshy conditions in the IIIrd c. AD (c. 1716 cal yr BP,

819 date $1,65 \mathrm{~cm}$ ) is reflected by the level of dark sediment known as the "Sarliève Dark Layer" (SU6B,

820 see Vernet, 2005; Vernet et al., 2011). This layer reflects a palustrine environment with reduced

821 detrital inputs, but appears in detail much more complex than depicted in previous works: four

822 different sub-layers indicate changing hydro-sedimentary conditions (F1, F2, and Fe/Mn in Fig. 11) in

823 the Sarliève basin from the IIIrd C. AD and during the Late Antiquity, similar to other Limagne

824 wetlands. The exact nature and causes of these quick changes remain unclear, but they are more

825 likely to be due to major modifications in landscape management than to climatic degradation

826 (Mayoral et al., 2020b), although this should be confirmed by further studies. The hydrosedimentary

827 dynamics after the Late Antiquity cannot be inferred from the sequence because of pedo- and

828 agroturbation; however, the presence of a marsh or lake in the basin during the Middle Ages is

829 known from historical sources (Trément et al., 2007). This medieval lake was finally drained in the

$830 \mathrm{XVII}$ th century, after which the Sarliève marsh became a permanently cultivated plain.

831 

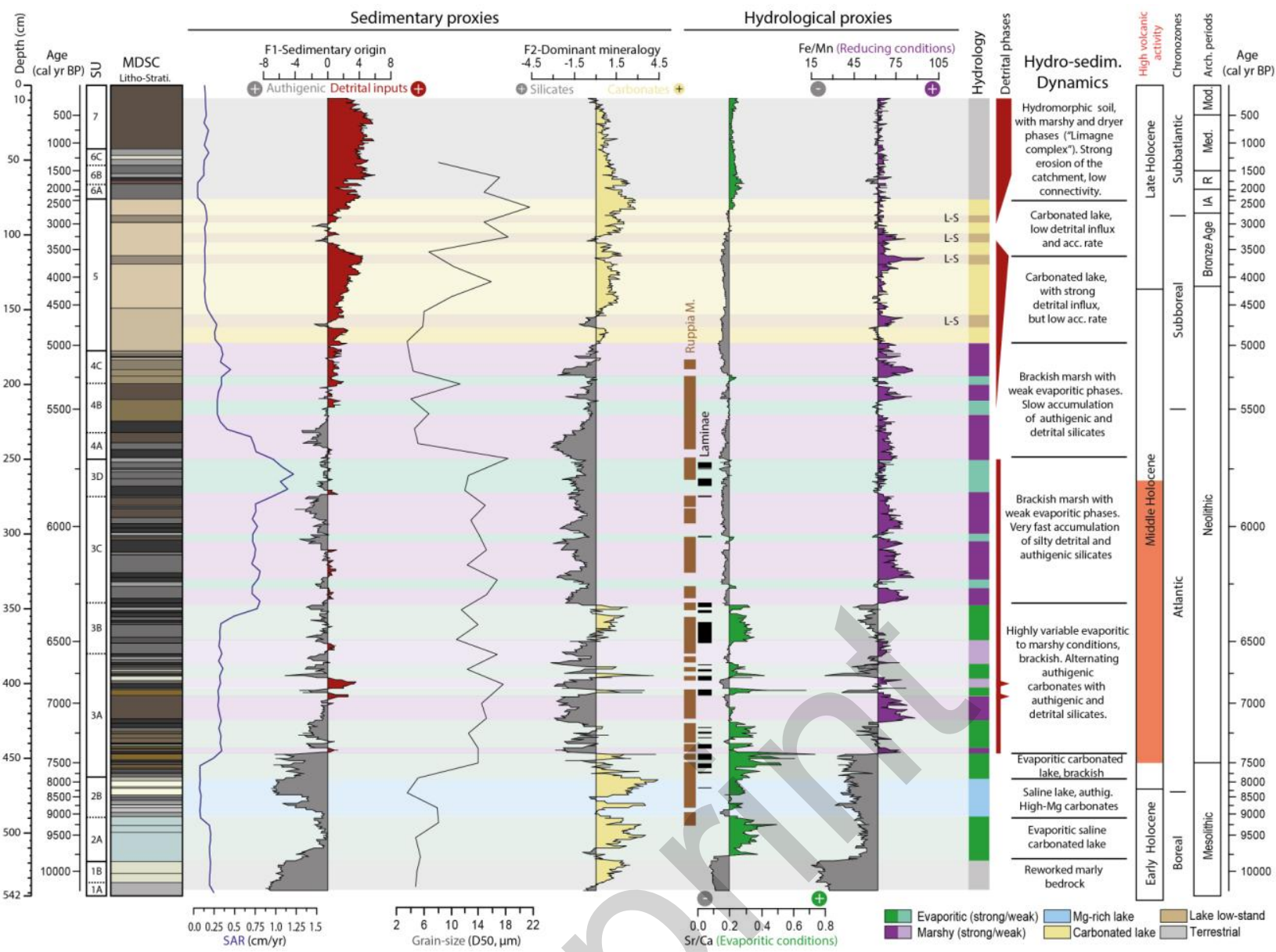

Figure 11. Multi-proxy reconstruction of Holocene hydro-sedimentary dynamics in the Sarliève marsh. 


\section{CONCLUSIONS}

Sedimentological and geochemical analyses were performed on a new sedimentary core from the

846 Sarliève marsh, and are interpreted within a radiocarbon-based Bayesian age-depth model

847 significantly more accurate than any previous models or estimations, which were in some cases

848 extremely divergent. On this basis we proposed a thorough review and reinterpretation of the

849 Holocene volcanic events and hydro-sedimentary history recorded in the sedimentary sequence.

850 We detected an array of new volcanic phenomena recorded in the Sarliève marsh: six (crypto)tephra

851 fallouts were identified, five of them previously unknown in the Sarliève sedimentary sequence (c.

$8529750,8500,7500,7400,6300$, and 5800 cal yr BP). Five unknown earthquakes (c. 6800, 6600, 6050,

8536100 , and 1600 cal yr BP) and two degassing events (c. 6950 and 6050 cal yr BP) were also detected

854 for the first time. This concentration of fallouts, earthquakes, and degassing episodes depict a

855 hitherto unsuspected phase of intense volcanic activity in the Limagne during the Middle Holocene,

856 between 7500 and 5800 cal yr BP. Three phases of residual volcanic impacts characterized by slow

857 leaching of previous ash deposits were detected between $10,250-9750,8500-7400$, and 5800-5100

858 cal yr BP. Although requiring further detailed studies and cross-validation, several of these findings

859 can be matched with known events, enriching the regional volcanic chronology, tephrochronology,

860 and seismochronology.

861 The hydro-sedimentary history of the Sarliève marsh was also substantially reviewed and

862 reinterpreted thanks to the new chronology and high-resolution analysis, with integration of the new

863 volcanic data. Consistent with previous works, our data suggest that between c. 9800 and 7800 cal yr

864 BP, the basin was endorheic and occupied by a small highly-mineral and saline waterbody with a

865 marked evaporitic regime. The basin evolved to a brackish marsh between 7800 and 7400 cal yr BP,

866 probably because of a wetter climate, but its hydrology became irregular with several evaporitic

867 episodes. From 7400 to 5700 cal yr BP, hydrological conditions became gradually wetter (especially 
868 from $6300 \mathrm{cal}$ yr BP onwards) and the basin received massive inputs of extremely well-sorted

869 siliceous silts. These sediments have characteristics compatible with reworked fine volcanic ash, probably discharged by the detected increase in volcanic activity during this period, and accumulated

871 in the marsh by wind or runoff. Our results suggest that the massive catchment-scale sedimentary

872 forcing during this phase was mainly volcanic, and that the role of climate and Neolithic societies

873 proposed in previous works was minor. These results, which should be confirmed by further works,

874 question the Holocene morpho-sedimentary narrative in Limagne.

875 From 5700 cal yr BP and immediately after the end of the phase of high volcanic activity, the sediment accumulation rate decays and the basin seems to return to something of a pre-forcing state, although with significantly wetter conditions. However, this phase is relatively short-lived, as from 5000 cal yr BP major changes occur: a rise in water level due to wetter conditions after the Mid-

879 Holocene climatic shift transformed the marsh into a carbonated freshwater lake, and an 880 anthropogenic detrital influx developed from $5500 \mathrm{cal}$ yr BP. This signal of increased erosion probably 881 due to the impacts of Late Neolithic societies on soils is consistent with previous works, and grows 882 more clearly after $5000 \mathrm{cal}$ yr BP. However, our results suggest a hitherto undetected lull in erosion 883 and detrital influx into the basin between 3600 and 3000 cal yr BP, probably related to a regionally 884 well-documented abandonment of habitat and decrease of activity during the Middle and the 885 beginning of the Late Bronze age, followed by a recovery at the end of the period. A series of low886 stands of the lake indicating dryer periods occurred during this phase (c. 4750-4600, 3750-3600, 887 3350-3200, and 2950-2800 cal yr BP). Their synchrony with similar events in the Rhône valley and 888 the western alpine lakes point to climatic control. However, these small variations in precipitation 889 are not clearly connected with detrital influx from the catchment and anthropogenic erosion, 890 suggesting here a rather reduced influence of climate on protohistoric societies.

891 The results suggest that this lake could have been drained c. 2550 cal yr BP, i.e., several centuries 892 earlier than previously accounted. This allows us to hypothesize that Early Iron age societies could 
have had a significant hydraulic capacity, and pulls back the date for this major threshold in

894 anthropogenic impacts on wetlands. The development of a hydromorphic soil after this first major drainage phase shows that there is no hiatus in the sedimentary sequence between the late Iron Age and the IIIrd c. AD (Roman times), opening new possibilities for palaeoenvironmental studies of this period at Sarliève. Finally the Sarliève Dark Layer, corresponding to the development of a marsh from c. 1716 cal yr BP and during the Late Antiquity, appears more complex than previously thought. Its interpretation as the result of rapid hydro-sedimentary changes due to land-use modifications, similar to other Limagne wetlands, demands dedicated studies.

Ultimately, this work outlines the complexity and non-linearity of the interactions between hydrosedimentary systems, climate, volcanos, and Protohistoric societies, and highlights the utility of highresolution multiproxy analysis of sedimentary archives and the crucial importance of reliable agedepth models to disentangle the causality. In Limagne, where high quality and well-dated Holocene palaeoenvironmental records are particularly rare, the results of this study should form a cornerstone for forthcoming detailed studies.

\section{ACKNOWLEDGEMENTS}

This work was funded by the Conseil Départemental du Puy-de-Dôme (F.), within the program “L’Oppidum de Gergovie: contexte Géomorphologique, Paléoenvironnemental et Géoarchéologique“ (Dir. Y. Miras \& E. Defive). The authors want to acknowledge the landowner, M. Vivier, who allowed access to his fields. We are also grateful to a number of people who contributed to this work with their support in the field, laboratory assistance, administrative work, or valuable scientific discussions: Aude Beauger, Elisabeth Allain, Ana Ejarque, Arthur Ancrenaz, Laura Benedito, Yann Deberge, Manon Cabanis, Franck Vautier, Bertrand Dousteyssier, Florian Couderc, Delphine Latour, Anne-Lise Develle, Marion Dacko, Bruno Depreux, Hector Orengo and Marc Récoché. Finally, we express sincere thanks to the anonymous reviewers for their remarks and critical reading of the manuscript. 


\begin{tabular}{|c|c|c|c|}
\hline \multicolumn{2}{|c|}{ SU } & $\begin{array}{l}\text { Depth } \\
(\mathrm{cm} .)\end{array}$ & Description (color, texture, inclusions, sed. structures, pedofeatures) \\
\hline \multicolumn{2}{|c|}{7} & $0-42.5$ & $\begin{array}{l}\text { Topsoil. Grey silty clays, brownish at the top, sparse sands and granules, pedogenic aggregation (blocky } \\
\text { subangular to granular) }\end{array}$ \\
\hline \multirow{3}{*}{6} & 6C & $42.5-53.5$ & $\begin{array}{l}\text { Grey silty clays, including abundant beige mottles, some dark mottles, sparse sands and granules, pedogenic } \\
\text { aggregation (blocky subangular to granular) }\end{array}$ \\
\hline & $6 B$ & $53.5-66$ & $\begin{array}{l}\text { Complex level including several layers of dark brown, dark-grey to black, and grey silty clays, small beige and } \\
\text { dark mottles and sparse sands and granules ("Sarliève Dark Layer"). Pedogenic aggregation (blocky } \\
\text { subangular to granular) disturbed by post-depositional deformations (mutual inclusions of different layers) }\end{array}$ \\
\hline & $6 A$ & $66-76$ & $\begin{array}{l}\text { Dark-grey silty clays with abundant small light and dark mottles, sparse sands and pedogenic aggregation } \\
\text { (blocky subangular, top) }\end{array}$ \\
\hline \multicolumn{2}{|c|}{5} & 76-177.5 & $\begin{array}{l}\text { Homogeneous light-grey to beige clays (with some sections slightly darker), sparse silty and sandy particles, } \\
\text { some small dark dots, and traces of incipient pedogenesis from upper levels (incipient aggregation above } 100 \\
\text { cm -blocky subangular to angular- and small rootlets in all the unit). }\end{array}$ \\
\hline \multirow{3}{*}{4} & $4 C$ & 177.5-199.5 & $\begin{array}{l}\text { Succession of layers of dark-grey to light-grey and brownish-grey clays, rare and sparse Ruppia maritima } \\
\text { seeds (base), beige and dark small mottles in layers. Few small reddish oxidation mottles at the base. One } \\
\text { isolated dark layer at the top of the unit. }\end{array}$ \\
\hline & 4B & 199.5-232 & $\begin{array}{l}\text { Brownish grey clays, with Ruppia maritima seeds, sometimes with small dark mottles. Two centimetric } \\
\text { intrusions of brown clays, with pedogenic aggregation (subangular to granular), rich in big vegetal debris, and } \\
\text { sparse sands and granules. }\end{array}$ \\
\hline & 4A & $232-249$ & Grey to dark-grey clays, with some Ruppia maritima seeds. \\
\hline \multirow{4}{*}{3} & 3D & $249-274,5$ & $\begin{array}{l}\text { Light-grey and grey clays, with some Ruppia maritima seeds sometimes bedded. Very abundant and very fine } \\
\text { (infra-mm) dark, brown, and beige, sometimes reddish laminae, diffuse to very well marked, in bundles or } \\
\text { isolated. }\end{array}$ \\
\hline & $3 C$ & $274.5-346$ & $\begin{array}{l}\text { Grey, dark-grey, and brownish grey clay layers, sometimes with abundant Ruppia maritima seeds, and very } \\
\text { rare laminae. Lower half disturbed by SSDS (micro-faulting, intrusion of liquefied material from lower levels). }\end{array}$ \\
\hline & 3B & $346-380$ & $\begin{array}{l}\text { Grey to dark-grey clays, sometimes with abundant Ruppia maritima seeds. Very abundant and very fine } \\
\text { brown, greenish, dark, and beige laminae, isolated or in bundles. SSDS at the top (cusp structure, load cast, } \\
\text { micro-faulting). }\end{array}$ \\
\hline & $3 A$ & $380-462.5$ & $\begin{array}{l}\text { Layers of dark-grey, grey, brown, beige, and greenish clay, with abundant Ruppia maritima seeds. Abundant } \\
\text { and fine (infra-mm) but also thick (millimetric) beige, brown, dark, and greenish laminae (or bedded } \\
\text { maculae) more or less defined and sometimes arranged in bundles or in irregular beige-brown-grey } \\
\text { sequences with Ruppia seeds. Central and upper part disturbed by SSDS (mixed layer, intruded material, } \\
\text { mushroom-like structure, micro-faulting). }\end{array}$ \\
\hline \multirow{2}{*}{2} & 2B & $462.5-489$ & Diffuse light-grey to beige clay layers with some Ruppia maritima seeds, one brown diffuse lamination. \\
\hline & $2 A$ & $489-519$ & Quasi homogeneous, very diffuse layers of beige to bluish-grey clays with dark and beige small mottles \\
\hline \multirow{2}{*}{1} & 1B & $519-533$ & Beige silty clays with some fine sand, some darker mottles (top) \\
\hline & 1A & $533-542$ & Greyish-beige silty clays with some fine sands, several beige and grey mottles \\
\hline
\end{tabular}




\section{REFERENCES}

Armit, I., Swindles, G. T., Becker, K., Plunkett, G., \&Blaauw, M., (2014). Rapid climate change did not cause population collapse at the end of the European Bronze Age. Proceedings of the National Academy of Sciences, 111, 17045-17049.

Ayris, P. M., \&-Delmelle, P., (2012ł. The immediate environmental effects of tephra emission. Bulletin of Volcanology, 74, 1905-1936.

Bajard, M., Sabatier, P., David, F., Develle, A.-L., Reyss, J.-L., Fanget, B., Malet, E., Arnaud, D., Augustin, L., Crouzet, C., Poulenard, J., \&Arnaud, F., (2015ł. Erosion record in Lake La Thuile sediments (Prealps, France): Evidence of montane landscape dynamics throughout the Holocene. The Holocene, 26, 350-364.

Baldini, J. U. L., Brown, R. J., \& Mawdsley, N., (2018). Evaluating the link between the sulfur-rich Laacher See volcanic eruption and the Younger Dryas climate anomaly. Climate of the Past- 14, 969-990.

Ballut, C., f2000ł. Evolution environnementale de la Limagne de Clermont-Ferrand au cours de la seconde moitié de l'holocène (Massif central français). Université de Limoges.

Barathon, J., \&Valleix, J., (1993ł. Les processus érosifs en Limagne clermontoise : aspects historique et contemporain d' un phénomène social ( Erosion processes in Limagne around Clermont : historical and contemporary aspects of a social phenomenon ). Bulletin de l'Association de géographes français- 5, 471-488.

Beck, C., (2009ł. Late Quaternary lacustrine paleo-seismic archives in north-western Alps: Examples of earthquake-origin assessment of sedimentary disturbances. Earth-Science Reviews; 96, 327344.

Berger, J-F., Brochier, J. L., Vital, J., Delhon, C., \&Thiébault, S., (2007ł. Nouveau regard sur La dynamique des paysages et l'occupation humaine à L'Âge du Bronze en moyenne vallée du Rhône. In H. Richard, C. Mordant, \& M. Magny (Eds.), Environnements et cultures à l'Age du bronze en Europe occidentale (p. 399). Paris: Editions du CTHS.

Berger, J-F., Carozza, J.-M., Carozza, L., Castanet, C., Cubizolle, H., Deschodt, L., Franc, O., Ghilardi, M., Lespez, L., Vannière, B., Salvador, P. G., Argant, J., Brochier, J. É., \&-Germaine, M.-A., ł2018ł. Climat et environnements : les étapes de la première anthropisation de l'espace (6000-2000 BCE) en France. In J. Guilaine \& D. Garcia (Eds.), La protohistoire de la France (p. 540). Hermann.

Bernigaud, N., Berger, J.-F., Bouby, L., Delhon, C., \&-Latour-Argant, C., (2014). Ancient canals in the valley of Bourgoin-La Verpillière (France, Isère): morphological and geoarchaeological studies of irrigation systems from the Iron Age to the Early Middle Ages (8th century beBC-6th century adAD). Water History, 6, 73-93.

Blaauw, M., (2012ł. Out of tune: The dangers of aligning proxy archives. Quaternary Science Reviews, $36,38-49$.

Blaauw, M., \& Christen, J. A., (2011ł. Flexible paleoclimate age-depth models using an autoregressive gamma process. Bayesian Analysis, 6, 457-474.

Blott, S. J., \& Pye, K., (2001). Gradistat: A Grain Size Distribution and Statistics Package for the Analysis of Unconcolidated Sediments. Earth Surface Processes and Landforms; 26, 1237-1248. 
Boivin, P., Besson, J.-C., Briot, D., Gourgaud, A., Labazuy, P., Langlois, E., De Larouzière, F.-D., Livet, M., Médard, E., Mergoil, J., Merciecca, C., Miallier, D., Morel, J.-M., Thouret, J.-C., \&-Vernet, G., (2017ł. Volcanologie de la Chaine des Puys (6e Edition.). Château de Montlosier, 63970 Aydat: Parc Naturel Régional des Volcans D’Auvergne.

Boivin, P., Besson, J.-C., Ferry, P., Gourgaud, A., Miallier, D., Thouret, J.-C., \&-Vernet, G., ł2011ł. Le point sur l'eruption du lac Pavin il y a 7000 ans. Revue des Sciences Naturelles d'Auvergne, 7475, 45-55.

Bouiller, R., f1979ł. Minute de la carte Géologique de la France à 1:50000, feuille 717 (VeyreMonton). BRGM.

Bourdier, J. L., Boivin, P., Gourgaud, A., Camus, G., Vincent, P. M., \&-Lenat, J. F., f1994ł. Le volcanisme. Manuels et méthodes - Bureau de recherches géologiques et minières. BRGM éditions.

Bréhéret, J.-G., Macaire, J.-J., Fleury, A., Fourmont, A., \&-Soulié-Märsche, I., (2003ł. Indices de confinement dans les dépôts lacustres holocènes de Sarliève (Limagne, France). Comptes Rendus Geoscience, 335, 479-485.

Bréhéret, J. G., Fourmont, A., Macaire, J. J., \&-Négrel, P., (2008). Microbially mediated carbonates in the Holocene deposits from Sarliève, a small ancient lake of the French Massif Central, testify to the evolution of a restricted environment. Sedimentology, 55, 557-578.

BRGM, (1973ł. Carte Geologique 1/50.000 n693 (Clermont-Ferrand). (BRGM, Ed.), Orléans: BRGM.

Brown, T. aA., Nelson, D. E., Mathewes, R. W., Vogel, J. S., \&-Southon, J. R., ł1989ł. Radiocarbon dating of pollen by accelerator mass spectrometry. Quaternary Research, 32, 205-212.

Carozza, L., Berger, J-F., Burens, A., \&Marcigny, C., \$2015ł. Society and environment in Southern France from the 3rd millenium $B C$ to the beginning of the 2 nd millenium $B C$ a tipping point? In 2200 BC - Ein Klimasturz als Ursache für den Zerfall der Alten Welt ? 2200 BC - A climatic breakdown as a cause for the collapse of the old world ? (pp. 833-844).

Cas, R. A. F., \&-Wright, J. V., (1987). Volcanic Successions. Modern and Ancient. London: Springer Netherlands.

Chapron, E., Chassiot, L., Foucher, A., \&-Lavrieux, M., f2018ł. An up-to-date Holocene catalog of sedimentary events recorded in volcanic lakes from the French Massif Central. In ISC 2018 20th International sedimentological Congress.

Couderc, F., (2019ł. La basse Auvergne (Puy-de-Dôme, sud Allier) : un espace privilégié pour l'étude des territoires et des paysages de l'âge du Bronze. In Colloque international anniversaire de I' APRAB (pp. 94-97). Bayeux: APRAB.

Cuven, S., Francus, P., \&-Lamoureux, S., (2011). Mid to Late Holocene hydroclimatic and geochemical records from the varved sediments of East Lake, Cape Bounty, Canadian High Arctic. Quaternary Science Reviews, 30, 2651-2665.

Dearing, Jehn. A., (1999ł. Using the Bartington MS2 System. Environmental Magnetic Susceptibility; 52.

Delpuech, A., (1987). Deux millions d’années en Auvergne: archéologie et autoroute A 71. Marsat: Direction des antiquités d'Auvergne; SAPRR. 
Dunbar, N. W., Iverson, N. A., Van Eaton, A. R., Sigl, M., Alloway, B. V., Kurbatov, A. V., Mastin, L. G., McConnell, J. R., \&-Wilson, C. J. N., (2017). New Zealand supereruption provides time marker for the Last Glacial Maximum in Antarctica. Scientific Reports; 7, 3-10.

Fisher, R., (1963). Bubble-wall texture and its significance. Journal of Sedimentary Research, 33, 224227.

Fisher, R. V., \&-Schmincke, H.-U., (1984). Pyroclastic Rocks. Berlin Heidelberg New York Tokyo: Springer-Verlag.

Fletcher, W. J., Debret, M., \& Sanchez-Goñi, M.-F., (2013). Mid-Holocene emergence of a lowfrequency millennial oscillation in western Mediterranean climate: Impications for past dynamics of the North Atlantic atmosphere westerlies. The Holocene 23, 153-166.

Fletcher, W. J., Zielhofer, C., Mischke, S., Bryant, C., Xu, X., \&-Fink, D., (2017). AMS radiocarbon dating of pollen concentrates in a karstic lake system. Quaternary Geochronology, 39, 112-123.

Fourmont, A., (2006). Quantification de l'érosion et de la sédimentation dans le bassin de Sarliève (Massif Central, France) au tardiglaciaire et à l'Holocène : Impact des facteurs naturels et anthropiques. Université François Rabelais-Tours.

Fourmont, A., Macaire, J.-J., Bréhéret, J.-G., Argant, J., Prat, B., \&-Vernet, G., ł2006ł. Tephras in lacustrine sediments of the Sarliève marsh (French Massif Central): age and preservation. Comptes Rendus Geoscience, 338, 1141-1149.

Fourmont, A., Macaire, J. J., \& Bréhéret, J. G., (2009). Contrasted Late Glacial and Holocene hydrology of Sarliève paleolake (France) from sediment geometry and detrital versus biochemical composition. Journal of Paleolimnology, 41, 471-490.

Fournier, J., Bonnot-Courtois, C., Paris, R., Voldoire, O., \& Le Vot, M., ł2012ł. Analyses Granulométriques - Principes et Méthodes. Dinard: CNRS.

Gachon, L., (1963). Contribution à l'etude du Quaternaire récent de la Grande Limagne marnocalcaire : morphogenèse et pédogenèse. Institut National Agronomique.

Grimm, E. C., Maher, L. J., \& Nelson, D. M., ł2009ł. The magnitude of error in conventional bulksediment radiocarbon dates from central North America. Quaternary Research, 72, 301-308.

Guilloré, P., f1980ł. Méthode de fabrication mécanique et en série des lames minces (2ème éditi.). Paris, Grignon: CNRS et INA-PG.

Hatté, C., Bréhéret, J.-G., Jacob, J., Argant, J., \&Macaire, J.-J., (2013ł. Refining the Sarliève paleolake (France) neolithic chronology by combining several radiocarbon approaches. Radiocarbon, 55, 979-992.

Heiken, G., \&Wohletz, K., (1985ł. Volcanic ash. Berkeley: University of California Press.

Heiri, O., Lotter, A. F., \&-Lemcke, G., $\{2001$ t. Loss on ignition as a method for estimating organic and carbonate content in sediments: reproducibility and comparability of results. Journal of Paleolimnology, 25, 101-110.

Hinschberger, F., Fourmont, A., Macaire, J.-J., Breheret, J.-G., Guerin, R., \& Bakyono, J.-P., $\{2006 \nmid$. Contribution of geophysical surveys to the study of fine grained lacustrine sediments . Application to the Sarliève marsh ( Massif Central , France ). Bull. Soc. géol. France, 177, 311322. 
Joly, D., Brossard, T., Cardot, H., Cavailhes, J., Hilal, M., \& Wavresky, P., f2010ł. Les types de climats en France, une construction spatiale - Types of climates on continental France, a spatial construction. Cybergéo : European Journal of Geography, 1-23.

Jouannic, G., Walter-Simonnet, A. V., Bossuet, G., Cubizolle, H., Boivin, P., Devidal, J. L., \& Oberlin, C., (2014). Occurrence of an unknown Atlantic eruption in the Chaîne des Puys volcanic field (Massif Central, France). Journal of Volcanology and Geothermal Research, 283, 94-100.

Juvigné, E., Bastin, B., \&-Gewelt, M., ł1986ł. Découverte de retombées volcaniques d'âge Holocène dans la Chaîne des Puys septentrionale (Massif Central, France). Revue des Sciences Naturelles d'Auvergne, 52 .

Juvigné, E., \& Gilot, E., (1986). Ages et zones de dispersion de téphra émises par les volcans du Montcineyre et du Lac Pavin (Massif Central, France). Zeitschrift deutschen geologischen Gesellschaft 137, 613-623.

Kaufman, D., McKay, N., Routson, C., Erb, M., Dätwyler, C., Sommer, P. S., Heiri, O., \&Davis, B., (2020). Holocene global mean surface temperature, a multi-method reconstruction approach. Scientific Data; 7, 1-13.

Kremer, K., Wirth, S. B., Reusch, A., Fäh, D., Bellwald, B., Anselmetti, F. S., ... \& Strasser, M., (2017). Lake-sediment based paleoseismology: Limitations and perspectives from the Swiss Alps. Quaternary Science Reviews, 168, 1-18.

Kylander, M. E., Ampel, L., Wohlfarth, B., \&Veres, D., ł2011). High-resolution X-ray fluorescence core scanning analysis of Les Echets (France) sedimentary sequence: new insights from chemical proxies. Journal of Quaternary Science- 26, 109-117.

Kylander, M. E., Klaminder, J., Bindler, R., \&-Weiss, D. J., (2010ł. Natural lead isotope variations in the atmosphere. Earth and Planetary Science Letters, 290, 44-53.

Lavrieux, M., Disnar, J.-R., Chapron, E., Breheret, J.-G., Jacob, J., Miras, Y., Reyss, J.-L., Andrieu-Ponel, V., \&Arnaud, F., +2013ł. $6700 \mathrm{yr}$ sedimentary record of climatic and anthropogenic signals in Lake Aydat (French Massif Central). The Holocene, 23, 1317-1328.

Lespez, L., Carozza, L., Berger, J., Kuzucuoğlu, C., Ghilardi, M., Carozza, J., \&-Vannière, B., ł2016ł. Rapid climatic change and social transformations Uncertainties, adaptability and resilience. In The Mediterranean Region under Climate Change-A Scientific Update (p. 738). AllEnvi.

Lindbo, D. L., Stolt, M. H., \&-Vepraskas, M. J., (2010). Redoximorphic Features. In Interpretation of Micromorphological Features of Soils and Regoliths (pp. 129-147). Elsevier.

Macaire, J. J., Fourmont, A., Argant, J., Bréhéret, J. G., Hinschberger, F., \&-Trément, F., (2010ł. Quantitative analysis of climate versus human impact on sediment yield since the Lateglacial: The Sarliève palaeolake catchment (France). The Holocene, 20, 497-516.

Magny, M., (2004). Holocene climate variability as reflected by mid-European lake-level fluctuations and its probable impact on prehistoric human settlements. Quaternary International, 113, 6579.

Magny, M., Bossuet, G., Gauthier, É., Richard, H., Vannière, B., Billaud, Y., Marguet, A., \&Mouthon, J., (2007). Variations du climat pendant l'Âge du Bronze au centre-ouest de l'Europe : vers l'établissement d'une chronologie à haute résolution. In C. Mordant, H. Richard, \& M. Magny (Eds.), Environnements et cultures à l'Âge du Bronze en Europe Occidentale- Documents préhistoriques $n^{\circ} 21$ (p. 400). Besançon: CTHS. 
Martin, C., Ménot, G., Thouveny, N., Davtian, N., Andrieu-Ponel, V., Reille, M., \&-Bard, E., ł2019ł. Impact of human activities and vegetation changes on the tetraether sources in Lake St Front (Massif Central, France). Organic Geochemistry, 135, 38-52.

Martínez Cortizas, A., López-Merino, L., Bindler, R., Mighall, T., \&-Kylander, M. E., (2016ł. Early atmospheric metal pollution provides evidence for Chalcolithic/Bronze Age mining and metallurgy in Southwestern Europe. Science of the Total Environment, 545-546, 398-406.

Mayoral, A., (2018t. Analyse de sensibilité aux forçages anthropo-climatiques des paysages protohistoriques et antiques du plateau volcanique de Corent ( Auvergne ) et de ses marges par une approche géoarchéologique pluri-indicateurs. Université Clermont Auvergne.

Mayoral, A., Berger, J. F., Peiry, J. L., Ledger, P., \&-Miras, Y., (2020ał. Five millennia of humanenvironment interactions reconstructed from pedosedimentary archives of the Lac du Puy wetland (Corent, Fr.). Catena- 195, 104908.

Mayoral, A., Granai, S., Develle, A. L., Peiry, J. L., Miras, Y., Couderc, F., Vernet, G., \&-Berger, J. F., †2020bł. Early human impact on soils and hydro-sedimentary systems: Multi-proxy geoarchaeological analyses from La Narse de la Sauvetat (France). The Holocene- 30, 17801800.

Mayoral, A., Peiry, J. L., Berger, J. F., Simon, F. X., Vautier, F., \&Miras, Y., (2018). Origin and Holocene geomorphological evolution of the landslide-dammed basin of la Narse de la Sauvetat (Massif Central, France). Geomorphology, 320, 162-178.

Miallier, D., Sanzelle, S., Pilleyre, T., Vernet, G., Brugière, S., \&-Danhara, T., (2004ł. Nouvelles données sur le téphra de Sarliève et le téphra CF7, marqueurs chrono-stratigraphiques de Grande Limagne (Massif central, France). Comptes Rendus Geoscience, 336, 1-8.

Milcent, P.-Y., \&-Mennessier-Jouannet, C., \$2007ł. Entre déterminisme environnemental et processus historiques: formes et modalités d'occupation du sol en Basse Auvergne du Bronze Final au début du second Age du Fer. In H. Richard, M. Magny, \&-C. Mordant (Eds.), Environnements et cultures à l'Âge du Bronze en Europe Occidentale- Documents préhistoriques n 21 (p. 399). Paris: CTHS.

Miras, Y., (2016). HDR-Hétérogénéité des paysages de montagne, variabilités des systèmes d'exploitation et transformations environnementales depuis le Néolithique : approches intégratives, pluri-échelles et multi-proxies. Université Blaise Pascal.

Monecke, K., Anselmetti, F. S., Becker, A., Schnellmann, M., Sturm, M., \& Giardini, D., ł2006ł. Earthquake-induced deformation structures in lake deposits: A Late Pleistocene to Holocene paleoseismic record for Central Switzerland. Eclogae Geologicae Helvetiae, 99(3), 343-362.

Prat, B., $\{2006\}$. Systèmes agropastoraux et milieux périurbains en Basse Auvergne au cours des trois derniers millénaires: contribution de l'analyse palynologique à l'étude des intéractions sociétésmilieux. Thèse de doctorat, 368 pp.

Raynal, J-P., Vernet, G., \&-Daugas, J., \{2003ł. Evolution récente de la Limagne d'Auvergne ( France ) : impacts du volcanisme et aspects des peuplements humains au Tardiglaciaire et à l'Holocène . In C. Albore-Livadie \& and F. Ortolani (Eds.), Variazoni climatico-ambientali e impatto sull'uomo nell'area circum-mediterranea durante l'Olocene, Territorio storico et ambiente 3 (pp. 461475). Bari: Edipuglia.

Reimer, P. J., Austin, W. E. N., Bard, E., Bayliss, A., Blackwell, P. G., Bronk Ramsey, C., Butzin, M., Cheng, H., Edwards, R. L., Friedrich, M., Grootes, P. M., Guilderson, T. P., Hajdas, I., Heaton, T. J., 
Hogg, A. G., Hughen, K. A., Kromer, B., Manning, S. W., Muscheler, R., Palmer, J. G., Pearson, C., Van Der Plicht, J., Reimer, R. W., Richards, D. A., Scott, E. M., Southon, J. R., Turney, C. S. M., Wacker, L., Adolphi, F., Büntgen, U., Capano, M., Fahrni, S. M., Fogtmann-Schulz, A., Friedrich, R., Köhler, P., Kudsk, S., Miyake, F., Olsen, J., Reinig, F., Sakamoto, M., Sookdeo, A., \& Talamo, S., $\{2020)$. The IntCal20 Northern Hemisphere Radiocarbon Age Calibration Curve (0-55 cal kBP). Radiocarbon, 62, 725-757.

Riquier, V., Auxiette, G., Fechner, K., Loicq, S., \&-Toulemonde, F., (2015ł. Éléments de géographie humaine et économique à l'âge du Bronze et au premier âge du Fer dans la plaine de Troyes. Bulletin de la Société préhistorique française, 112, 339-367.

Rodríguez-Pascua, M. A., Calvo, J. P., De Vicente, G., \& Gómez-Gras, D., ł2000ł. Soft-sediment deformation structures interpreted as seismites in lacustrine sediments of the Prebetic Zone, SE Spain, and their potential use as indicators of earthquake magnitudes during the Late Miocene. Sedimentary Geology, 135(1-4), 117-135.

Sabatier, P., Dezileau, L., Briqueu, L., Colin, C., \& Siani, G., ł2010ł. Clay minerals and geochemistry record from northwest Mediterranean coastal lagoon sequence: Implications for paleostorm reconstruction. Sedimentary Geology, 228, 205-217.

Salminen, R., Batista, M. J., Bidovec, M., Demetriades, A., De Vivo, B., \&-De Vos, W., (2005t. FOREGS Geochemical Atlas of Europe, Part I* Background Information, Methodology, and Maps. Geol. Surv. Finland, Espoo.

Shanmugam, G., (2017). Global case studies of soft-sediment deformation structures (SSDS): Definitions, classifications, advances, origins, and problems. Journal of Palaeogeography, 6 , 251-320.

Steig, E. J., (1999). Mid-Holocene climate change. Science- 286(5444), 1485-1487.

Stockhecke, M., Sturm, M., Brunner, I., Schmincke, H. U., Sumita, M., Kipfer, R., ... \&Anselmetti, F. S., (2014). Sedimentary evolution and environmental history of Lake Van (Turkey) over the past 600000 years. Sedimentology, 61(6), 1830-1861.

Stuiver, M., \& Reimer, P. J., (1993). Extended 14C database and revised Calib 3.0 14C Age Calibration program. Radiocarbon, 35, 215-230.

Tinner, W., Lotter, A. F., Ammann, B., Conedera, M., Hubschmid, P., Van Leeuwen, J. F. N., \&-Wehrli, M., (2003). Climatic change and contemporaneous land-use phases north and south of the Alps 2300 BC to 800 AD. Quaternary Science Reviews, 22, 1447-1460.

Trément, F., Argant, J., Breheret, J.-G., Cabanis, M., Dousteyssier, B., Fourmont, A., Fournier, G., Liabeuf, R., Loison, G., Lopez-Saez, J.-A., Macaire, J.-J., Marinval, P., Mennessier-Jouannet, C., Milcent, P.-Y., Prat, B., Rialland, Y., \&-Vernet, G.- (2007). Un ancien lac au pied de l'oppidum de Gergovie (Puy-de-Dôme). Gallia, 64, 289-351.

Trément, F., f2011t. Les arvernes et leurs voisins du Massif Central à l'Epoque Romaine-Une archéologie du développement des territoires, vol. I. Clermont-Ferrand: Revue D'auvergne, Alliance Universitaire d'Auvergne.

Van Daele, M., Moernaut, J., Silversmit, G., Schmidt, S., Fontijn, K., Heirman, K., Vandoorne, W., De Clercq, M., Van Acker, J., Wolff, C., Pino, M., Urrutia, R., Roberts, S. J., Vincze, L., \&-De Batist, M., (2014). The 600 yr eruptive history of Villarrica Volcano (Chile) revealed by annually laminated lake sediments. Geological Society of America Bulletin, 126, 481-498. 
Vernet, G., f2005ł. Rapport final d'opération de diagnostic et de fouille archéologique, bassin de Sarliève, Grande Halle d'Auvergne (Cournon, Pérignat-les-Sarliève et Aubière). Centre archéologique de Clermont-Ferrand.

Vernet, G., Henry, M. J., Cayrol, J., Parent, D., Wittmann, A., \& Cabanis, M., ł2011ł. CoURNON, Puyde-Dôme, Auvergne, Plaine de Sarliève. Rapport final d'opération de diagnostic. Centre Archéologique, Clermont-Ferrand.

Vernet, G., (2013ł. La séquence sédimentaire des gGravanches / gGerzat : enregistrement d'événements "catastrophiques» à valeur chronologique en thimagne d'zAuvergne (mMassif $\in$ Central, France). Quaternaire, 24, 109-127.

Vernet, G., (2019ł. Les produits pyroclastiques distaux du volcan de la Nugère : synthèse des données et découverte en contexte archéologique. The distal pyroclastic products of the Nugère volcano : synthesis of data and discoveries in archaeological context. Revue des Sciences Naturelles d'Auvergne, 83, 3-34.

Vernet, G., \&Raynal, J.-P., (2002ł. Éruptions trachytiques de la Chaîne des Puys (France) et leur impact sur les environnements. In Hommes et Volcans. De l'éruption à l'objet. XIVth Congress UISPP, Liege.

Wang, S., Ge, Q., Wang, F., Wen, X., \&-Huang, J., (2013). Abrupt climate changes of Holocene. Chinese Geographical Science, 23, 1-12.

Witham, C. S., Oppenheimer, C., \&Horwell, C. J., $\{2005+$. Volcanic ash-leachates: A review and recommendations for sampling methods. Journal of Volcanology and Geothermal Research, 141, 299-326.

Yansa, C., \& Long, D., (2007). Improving the Accuracy of Radiocarbon Chronologies from Lakesediment Cores: Testing for the 14C Reservoir Effect in Aquatic Macrophytes-CWS Venture Grant- Report of Findings.

Zielhofer, C., Köhler, A., Mischke, S., Benkaddour, A., Mikdad, A., \&Fletcher, W. J., (2019ł. Western Mediterranean hydro-climatic consequences of Holocene ice-rafted debris (Bond) events. Climate of the Past, 15, 463-475. 